\title{
A geochemical study of gersdorffite from the Trepça Mineral Belt, Vardar Zone, Kosovo
}

\author{
Sławomir MEDERSKI ${ }^{1 *}$, Marcin WOJSŁAW ${ }^{1}$, Jaroslav PRŠEK${ }^{1}$, Juraj MAJZLAN², Stefan KIEFER², \\ Burim ASLLANI ${ }^{3}$
}

\author{
${ }^{I}$ Faculty of Geology, Geophysics and Environmental Protection, AGH UST, University of Science and Technology, 30 Mickiewicz \\ Av.,30-059Krakow, Poland; mederski@agh.edu.pl \\ ${ }^{2}$ Institute of Geosciences, Friedrich Schiller University, Carl Zeiss Promenade 10, 07745 Jena, Germany; \\ ${ }^{3}$ E\&E Experts LLC, Prishtina, Kosovo \\ ${ }^{*}$ Corresponding author
}

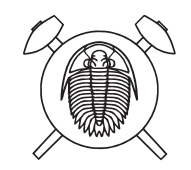

This work presents a textural and chemical study of gersdorffite from numerous small occurrences of hydrothermal $\mathrm{Pb}-\mathrm{Zn}+(\mathrm{Ni}-\mathrm{As}-\mathrm{Sb})$ mineralization from Trepça Mineral Belt (broad area of Stan Terg and Kizhnica-Hajvalia-Badovc ore field) hosted in hydrothermally altered serpentinites (listvenites). Mineral associations, textural relations and substitutional trends of gersdorffite recognized in Kizhnica, Mazhiq, Melenica, Vllahia and Selac are discussed based on microscopy and microprobe studies. The two types of paragenetic sequence with nickel mineralization are distinguished in studied localities: $\mathrm{Ni}-\mathrm{Fe}-\mathrm{Co}$ sulfides $\rightarrow \mathrm{Ni}$ sulfarsenides and sulfantimonides (in Kizhnica-Badovc and Melenica) and Ni sulfarsenides $\rightarrow \mathrm{Ni}-\mathrm{Fe}$ arsenide and diarsenide $\rightarrow \pm \mathrm{Ni}$ sulfides (Vllahia and Selac). Various substitution trends in studied GUS are detected: $\mathrm{Fe}+\mathrm{Co} / \mathrm{Ni}$ (all localities, except Selac); As/Sb - gersdorffite-ullmannite series (Kizhnica, Mazhiq, Vllahia VLX) and As $+\mathrm{Sb} / \mathrm{S}$ (Selac and Vllahia VL4). Based on As/S ratio, two different hydrothermal fluids were distinguished: narrow range and low As/S values (Kizhnica, Mazhiq, Melenica, Vllahia VLX), which suggest decreased As activity, mixing in the proximity of deposition site (Kizhnica, Mazhiq), broad range and high As/S values: increased As activity and disequilibrium crystallization (Selac, Vllahia VL4).

Keywords: gersdorffite solid solution, geochemistry, listvenite, Trepça Mineral Belt, Kosovo

Received: 16 February 2021; accepted: 27 May 2021; handling editor: J. Sejkora

The online version of this article (doi: 10.3190/jgeosci.322) contains supplementary electronic material.

\section{Introduction}

Gersdorffite, with the nominal formula NiAsS, is a common Ni-bearing sulfarsenide occurring in various hydrothermal and magmatic sulfide systems.

Minerals of the gersdorffite-ullmannite series (GUS) belong to the pyrite structure group. Three crystal structure variants of gersdorffite have been described: an ordered structure (space group $P 2_{1} 3$, ullmannite subgroup) (Bayliss and Stephenson 1967), a disordered structure (space group Pa3, pyrite supergroup) (Bayliss 1982) and distorted a disordered structure $P 1$ (Bayliss and Stephenson 1968).

Gersdorffite incorporates $\mathrm{Ni}, \mathrm{Co}$ and $\mathrm{Fe}$ in varying proportions (Klemm 1965) within the ternary gersdorffitecobaltite-arsenopyrite solid solutions. The Ni and Co endmembers of the series exhibit complete miscibility above $550^{\circ} \mathrm{C}$, but the Ni-Fe substitution is not complete (Yund 1962; Hem and Makovicky 2004a, 2004b). Moreover, the As and $\mathrm{S}$ content may deviate from the nominal molar 1:1 ratio, thus forming solid solutions towards krutovite ( $\mathrm{NiAs}_{2}$ ) and vaesite $\left(\mathrm{NiS}_{2}\right)$ (Yund 1962). In addition, the extensive As-Sb substitution (towards ullmannite) results in an additional dimension of solid-solution formation (Bayliss 1969).
Geochemical data of gersdorffite in hydrothermal systems were already provided by many authors (e.g., Grapes and Challis 1999; Fanlo et al. 2004, 2006; Belkin and Luo 2008; Voudouris et al. 2008; Ahmed et al. 2009; Harms 2010; Gervilla et al. 2012; Emam and Zoheir 2013; Mikuš et al. 2013; Qiu and Zhu 2015; Radosavljević et al. 2015; Ferenc et al. 2016; Kiefer et al. 2017; Voudouris et al. 2018; Rezazadeh et al. 2020; Števko and Sejkora 2020). In addition to those hydrothermal systems, gersdorffite appears in the so-called five-element (Ni-Co-As-Ag-Bi) association, which was extensively investigated (e.g., Watkinson et al. 1975; Kissin 1992; Markl et al. 2016; Moroni et al. 2019; Scharrer et al. 2019).

Nickel mineralization in the magmatic-hydrothermal systems occurring in the Vardar Zone is rare and only limited data are available. The mineralization with gersdorffite-ullmannite is part of $\mathrm{Pb}(\mathrm{Ag})-\mathrm{Zn}$ deposits and was described from the Rogozna ore field (ROF) at the boundary between Serbia and Kosovo. It is widespread in the Kaludjer deposit, in less amount at Plakaonica, whereas it was not reported in the largest central deposit Crnac (Radosavljević et al. 2015; Borojevic Šoštarić et al. 2011, 2013). Nickel mineralization in the Vardar zone 


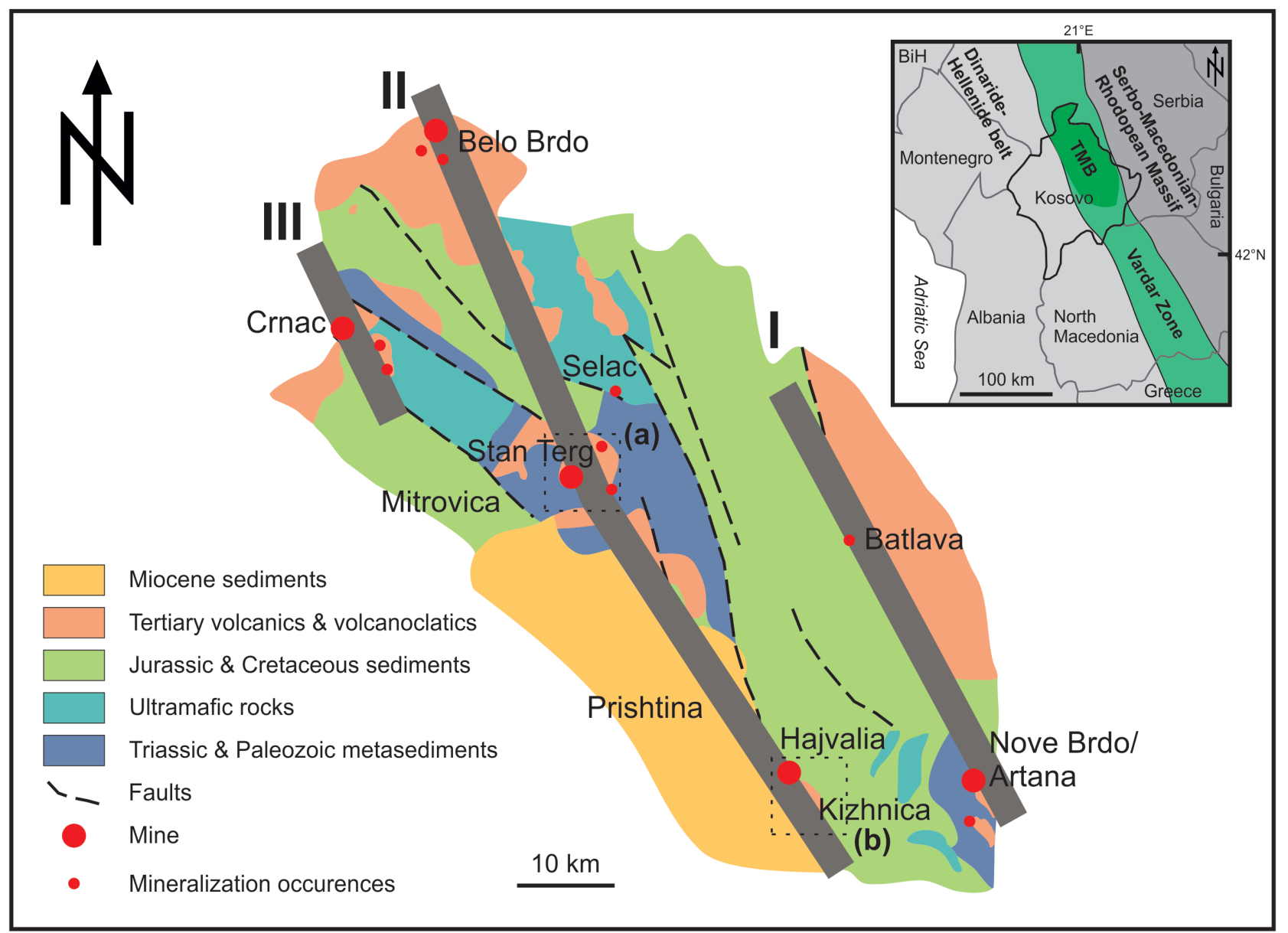

Fig. 1 - Simplified geological map of Vardar Zone and Trepça Mineral Belt (TMB) with marked metallogenic zones (I-III) (modified after Hyseni et al. 2010b; Strmić Palinkaš et al. 2013). I - Batlava-Artana Zone, II - Belo Brdo-Stan Terg-Hajvalia Zone, III - Crnac Zone, a- Stan Terg area, b- Hajvalia-Kizhnica-Badovc ore field.

contains sulfides, arsenides, and sulfarsenides and occurs in listvenite and vein-type mineralization. Other Ni-mineralization occurrences within the Vardar Zone were reported from several localities in Serbia: $\mathrm{Pb}-\mathrm{Zn}-\mathrm{Sb}$ Rajićeva Gora deposit (Janković and Zarić 1980), Ni-Fe-Cu(Pb, Zn, Sb) mineralization of the Asanovo Selo ore field (Stajević and Zarić 1984), the Rudnik $\mathrm{Pb}-\mathrm{Zn}-\mathrm{Cu}(\mathrm{Bi}, \mathrm{W}, \mathrm{Ag})$ ore field (Cvetković et al. 2011; Stojanović et al. 2018), the Lece $\mathrm{Pb}-\mathrm{Zn}-(\mathrm{Au})$ deposit (Radosavljević et al. 2011), where Ni sulfides, Ni sulfantimonides, as well as Ni arsenides were reported. Additionally, Serafimovski et al. (2010) described occurrences of Ni sulfides (bravoite and polydymite) in the $\mathrm{Cu}-\mathrm{Au}$ porphyry deposits of the Buchim-Damjan-Borov Dol Ore District in the territory of North Macedonia. Furthermore, the presence of GUS was described from the epithermal mineralization at Kamariza Mining District (Clemence Mine and "km3" locality) from the Lavrion ore field in Greece (Voudouris et al. 2008, 2018).

Earlier publications about the Stan Terg deposit and Kizhnica-Hajvalia-Badove ore field did not indicate the presence of $\mathrm{Ni}$ minerals in the hydrothermal system (Dangić 1993; Féraud and Deschamps 2009; Kołodziejczyk et al. 2016b). New research performed on various small occurrences in the broad Stan Terg area and the Kizhnica-Hajvalia-Badovc ore field shows that Ni mineralization seems to be fairly common in the hydrothermal systems in the Vardar Zone (Bal et al. 2019; Mederski et al. 2019; Wojsław et al. 2019).

The aim of this paper is the description of spatial and textural relations on the microscopic scale and chemical variability of gersdorffite from the $\mathrm{Ni}-\mathrm{As}-\mathrm{Sb}-\mathrm{S}-(\mathrm{Pb}-$ $\mathrm{Zn}-\mathrm{Cu}$ ) assemblages in various small occurrences in the broad surrounding of Stan Terg deposit and KizhnicaHajvalia-Badovc ore field.

\section{Geological setting}

The hydrothermal field of the $\mathrm{Pb}-\mathrm{Zn}-\mathrm{Ag}$ Stan Terg deposit is located in Kosovo, within the central part of Vardar Zone in the vicinity of Kopaonik granite massif, between the Serbo-Macedonian Massif to the east and 
the Dinarides to the west (Fig. 1) (Hyseni et al. 2010b). Together with the Kizhnica ore field, it is a part of the Trepça Mineral Belt (TMB) (Fig. 1). The main deposit in the area is Stan Terg, surrounded by numerous small occurrences and deposits (Fig. 2a). All deposits and occurrences have the same hydrothermal-metasomatic origin and Oligocene-Miocene age, related to the post-collisional magmatic activity (Strmić Palinkaš et al. 2013). The main lithologies in the TMB are represented by schists and phyllites of the Paleozoic crystalline basement, Triassic metasediments, and volcanoclastic rocks, Upper Triassic carbonates, as well as Jurassic ultramafic rocks (Elezaj 2009) (Fig. 1). Additionally, the Cretaceous complex is composed of series of flysch, carbonates, as well as volcanic and volcanoclastic rocks. Tertiary (Oligocene-Miocene) volcanic rocks are represented by andesites, trachytes, latites, and felsic pyroclastic rocks (Hyseni et al. 2010b; Strmić Palinkaš et al. 2013, 2016). The mineralization in the TMB area is hosted by Mesozoic carbonates at the contact with schists and the volcanic rocks of calc-alkaline affinity (at Stan Terg and Gjidoma) (Hyseni et al. 2010b) (Fig. 2a). It also occurs at the contact of serpentinites and volcanic rocks (at Vllahi, Selac, Melenica, Mazhiq, Kizhnica-Badovc) (Fig. 2b), or fills veins and veinlets in highly to moderately hydrothermally altered rocks - Mazhiq, Gumnishte, Badovc, Kizhnica. The mineralization forms elongated manto-like replacement orebodies, veins or is disseminated in the country rocks. The Stan Terg deposit and its broad surrounding is part of an extensive hydrothermal system with various mineralization styles, such as skarns, skarn-free carbonate-replacements, veins and breccias (Féraud and Deshamps 2009; Hyseni et al. 2010b; Strmić Palinkaš et al. 2013, 2016; Kołodziejczyk et al. 2015). The mineralogy of the deposits and occurrences is related to the mineralization styles and consists of various $\mathrm{Ca}-\mathrm{Mn}-\mathrm{Mg}-\mathrm{Fe}$ carbonates, quartz, skarn silicates, magnetite, sulfides and native elements (Dangić 1993; Féraud and

Fig. 2a - Simplified geological map of Stan Terg area (modified after Hyseni et al. 2010b). b - Simplified geological map of Kizhnica-Hajvalia-Badovc ore field (modified after Hyseni et al. 2010a). I - Hajvalia-Badove Zone, II - Kizhnica Zone, III - Okosnica Zone.

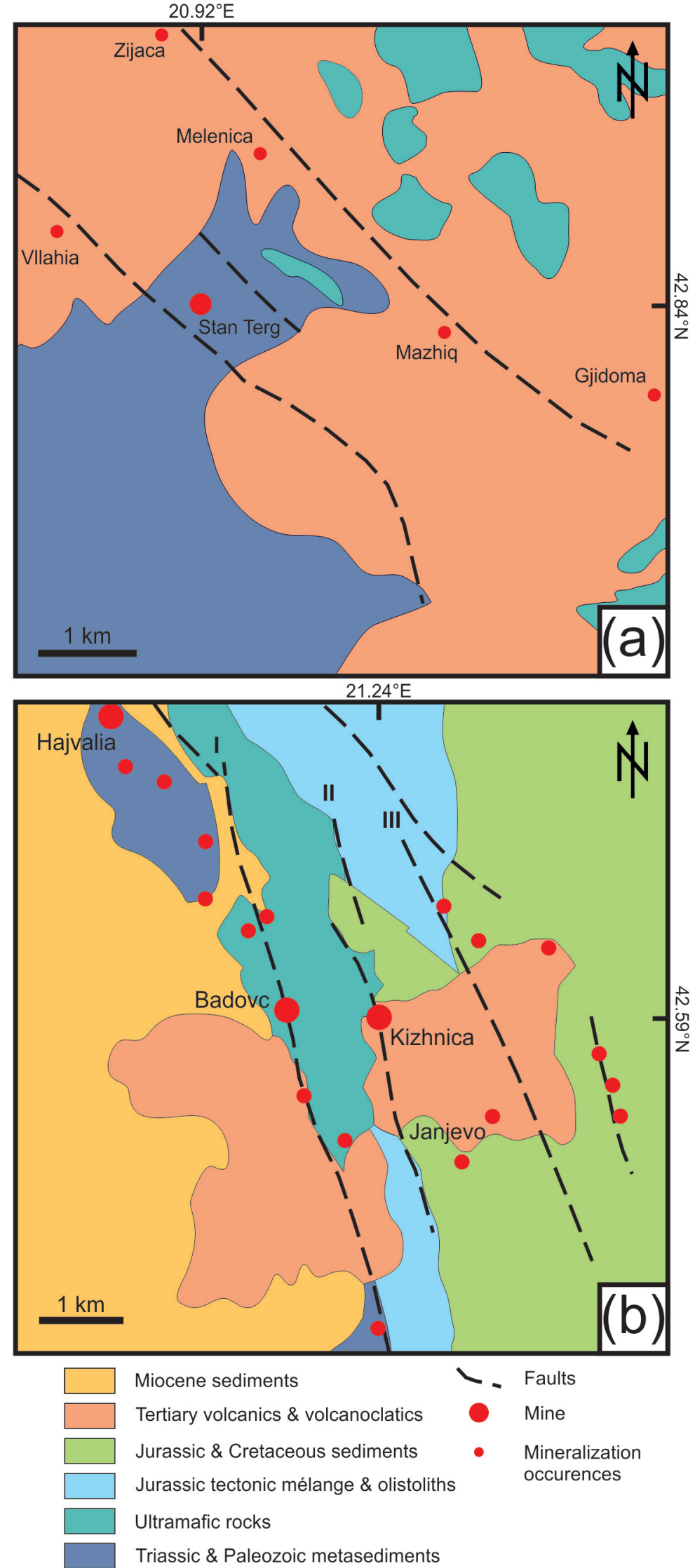



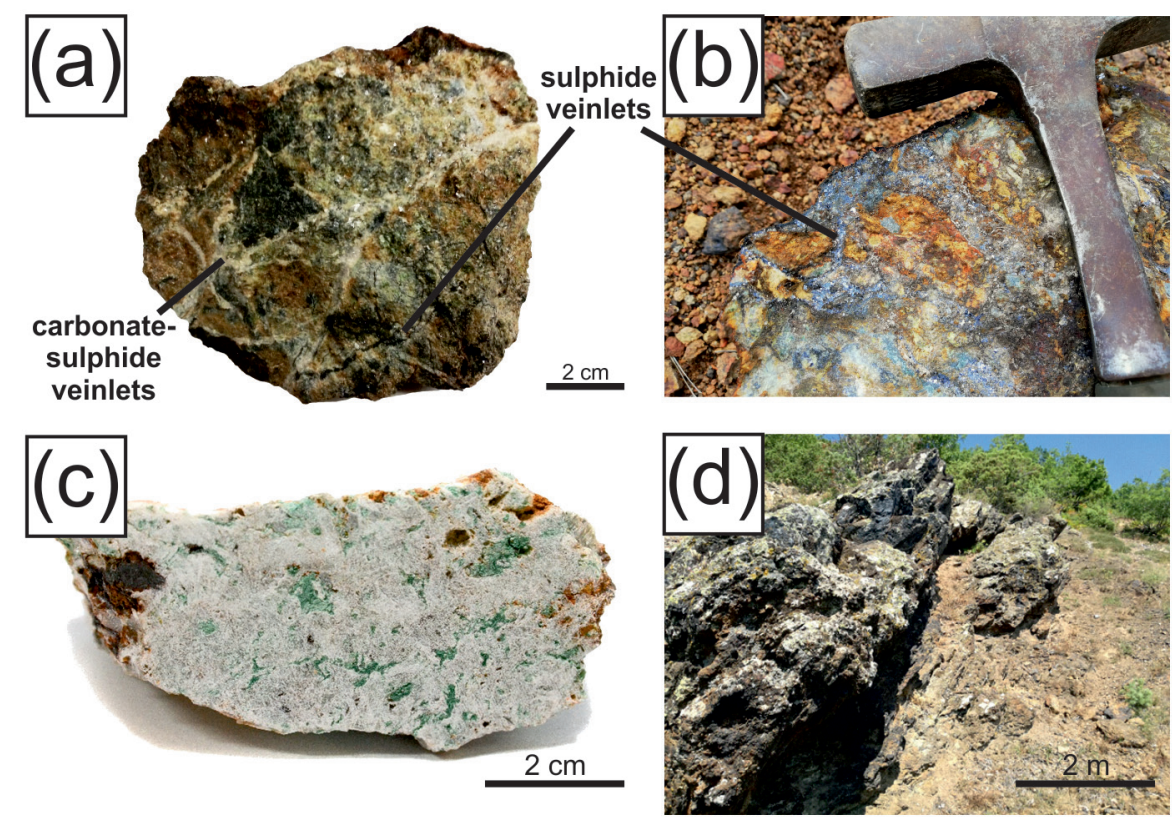

Fig. 3a - Carbonate-type listvenite with sulfide and calcite-sulfide veinlets from Kizhnica area. $\mathbf{b}$ - Sulfide-rich brecciated listvenite from Kizhnica area. c - Silicified listvenite from Vllahia. d - Gossan outcrop on listvenite from Vllahia.

Deshamps 2009). Sulfides are represented mainly by pyrite, arsenopyrite, sphalerite, galena, pyrrhotite, marcasite, tetrahedrite, and chalcopyrite. Additionally, $\mathrm{Bi}$ sulfosalts, Bi sulfotellurides, Sn minerals, gold, Ag minerals and $\mathrm{Pb}-\mathrm{Sb}$ sulfosalts were described recently (Kołodziejczyk et al. 2015, 2016a, b, 2017; Mederski et al. 2018; Węgrzynowicz et al. 2019). A similar $\mathrm{Pb}-\mathrm{Zn}-\mathrm{Sb}$ mineralization was observed in the Kizhnica-HajvaliaBadovc ore field (Hyseni et al. 2010a; Kołodziejczyk et al. 2016b; Mederski et al. 2019), including various $\mathrm{Pb}-\mathrm{Sb}$ sulfosalts, as well as accessory minerals such as Bi sulfosalts, Sn minerals and gold (Kołodziejczyk et al. 2016b; Mederski et al. 2019).

\section{Methods}

Ore samples for mineralogical and geochemical studies were collected from the five occurrences related to polymetallic $\mathrm{Pb}-\mathrm{Zn}$ ores from the Trepça Mineral Belt: Kizhnica-Badovc, Melenica, Mazhiq, Vllahia and Selac. Samples from each locality were examined macroscopically and more than 100 thin and polished sections were prepared for mineralogical studies, including textural relationships using reflected and transmitted light microscopy. Seventeen samples with gersdorffite from all investigated mineralized rocks were selected for further studies using electron microprobe analyses (EPMA). GUS members were analyzed using a JEOL Super Probe 8230 in the Laboratory of Critical Elements at Faculty of Geology Geophysics and Environmental Protection, AGH-UST, Kraków Poland. The following operating conditions and standards were used: accelerating voltage $20 \mathrm{kV}$, beam current $20 \mathrm{nA}$ and a beam diameter up to $5 \mu \mathrm{m}$. The following X-ray emission lines were used: $\mathrm{Cu} K_{\alpha}, \mathrm{S} K_{\alpha}, \mathrm{Fe} K_{\alpha}$, $\mathrm{As} L_{\alpha}, \mathrm{Sb} L_{\alpha}, \mathrm{Bi} M_{\alpha}, \mathrm{Ni} K_{\alpha}, \mathrm{Co} K_{\alpha}$. Natural mineral standards $\left(\mathrm{FeS}_{2}\right)$ and synthetic compounds $\left(\mathrm{Sb}_{2} \mathrm{~S}_{3}, \mathrm{CuFeS}_{2}, \mathrm{Bi}, \mathrm{Ni}\right.$, $\mathrm{Co}, \mathrm{GaAs}$ ) were used for calibration. All interferences between the element emission lines were calculated using autocorrections based on the standard materials. The detection limits for analyzed elements in gersdorffite were as follows: $\mathrm{Ni}-0.02$ wt. $\%, \mathrm{Fe}-0.03$ wt. $\%, \mathrm{Co}-$ 0.03 wt. $\%, \mathrm{~S}-0.012$ wt. $\%$, As -0.07 wt. $\%, \mathrm{Sb}-0.02$ wt. $\%, \mathrm{Bi}-0.03$ wt. $\%, \mathrm{Cu}-0.025$ wt. $\%$. All analyses of GUS were calculated on the basis of the sum of cations $(\mathrm{Fe}+\mathrm{Ni}+\mathrm{Co})=1$.

\section{Investigated material}

Samples for this study were collected from the various outcrops of the mineralized listvenite rocks in the broad Stan Terg and Kizhnica areas (Fig. 1). Listvenites are widespread in this area and were formed by hydrothermal alteration of the serpentinites in the tectonic zones or at the contact of serpentinites with volcanic rocks or the Triassic metamorphic series. They are represented by highly silicified and carbonatized rocks with macroscopically visible sulfide mineralization (Fig. 3a, b, c, d). Listvenites studied from each location differ mainly in polymetallic mineralization grades, as well as a degree of silicification and carbonate geochemistry. Relics of chromite, as well as green micas, are common in silicified rocks. Sulfides usually form veinlets, crosscutting listvenites, filling the voids, or are disseminated in highly altered rock. The most common sulfides in the veins are galena, 
Tab. 1 Description of the samples examined by EPMA from the Trepça Mineral Belt.

\begin{tabular}{|c|c|c|c|c|c|}
\hline Locality & Samples & Brief locality description & Brief sample description & Composition & Accessory Minerals \\
\hline \multirow{5}{*}{ 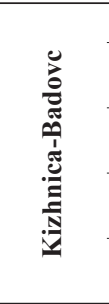 } & KZH2_12 & Badovc outcrop dump & Quartz-sphalerite breccia & Qz, Sp, Gn, Py & Gdf, Apy, Ccp, Ssy, Au \\
\hline & KZH2_6 & $\begin{array}{l}\text { Badove - listvenite outcrop at the NW } \\
\text { slope }\end{array}$ & Quartz-galena breccia & Qz, Gn, Py & Ccp, Ttr, Gdf, Pyh \\
\hline & KZH6_4 & $\begin{array}{l}\text { Badovc - listvenite outcrop at the NW } \\
\text { slope }\end{array}$ & $\begin{array}{l}\text { Strongly silicified listvenite } \\
\text { with galena veinlets }\end{array}$ & Qz, Gn, Carb & Py, Gdf, Ccp, Ttr \\
\hline & $\begin{array}{l}\text { SHA02_02a_1-3 } \\
\text { (3 samples) }\end{array}$ & $\begin{array}{l}\text { Badovc - listvenite outcrop at the NW } \\
\text { slope }\end{array}$ & $\begin{array}{l}\text { Carbonate listvenite with } \\
\text { disseminated mineralization }\end{array}$ & $\begin{array}{l}\text { Fe-Mn Carb, } \\
\text { Sp, Gn }\end{array}$ & $\begin{array}{l}\text { Gdf, Ccp, Mrc, Mlr, Hem, } \\
\text { Chr, Mag, Vio, Pld, Pn }\end{array}$ \\
\hline & SHA02_02a_4 & $\begin{array}{l}\text { Badovc - listvenite outcrop at the NW } \\
\text { slope }\end{array}$ & Quartz-sphalerite breccia & $\begin{array}{l}\text { Qz, Sp, Py, } \\
\text { Gn, Carb }\end{array}$ & Gdf, Pyh, Mrc, Hem \\
\hline$\frac{\mathscr{E}}{\tilde{D}}$ & T95_PYH4 & $\begin{array}{l}\text { Outcrop of carbonate vein in tectonic zone } \\
\text { in serpentinite }\end{array}$ & $\begin{array}{l}\text { Carbonate rock with } \\
\text { disseminated } \\
\text { Ni mineralization }\end{array}$ & Dol, Nc & $\begin{array}{l}\text { Muc, Gdf, Rmb, Mlr, Pld, } \\
\text { Ttr, Gn, Mgs }\end{array}$ \\
\hline \multirow{2}{*}{ 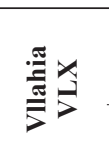 } & VLX_11_5A & Outcrop of the mineralized vein & $\begin{array}{l}\text { Breccia and silicified } \\
\text { volcanic tuff with massive } \\
\text { sulfides }\end{array}$ & $\mathrm{Qz}, \mathrm{Gn}, \mathrm{Sp}$ & Gdf, Rmb, Ccp, Cv, Ttr \\
\hline & VLX_11_2 & Outcrop of the mineralized vein & $\begin{array}{l}\text { Breccia, volcanic tuff with } \\
\text { disseminated sulfides }\end{array}$ & $\begin{array}{l}\text { Qz, Cal, Brt, } \\
\text { Gn, Sp }\end{array}$ & $\begin{array}{l}\text { Gdf, Mlr, Vio, Rmb, Py, } \\
\text { Cv, Ccp, Ttr }\end{array}$ \\
\hline \multirow{2}{*}{ 前节 } & VL4_4 & Listvenite outcrop close to the gossan & $\begin{array}{l}\text { Silicified listvenite with } \\
\text { disseminated mineralization }\end{array}$ & Qz, Carb, Gn & $\begin{array}{l}\text { Ttr, Sp, Bou, Ssy, Rmb, } \\
\text { Gdf, Lö, Sb-Rmb, Sb-Lö }\end{array}$ \\
\hline & VL4_1 & Listvenite outcrop close to the gossan & $\begin{array}{l}\text { Silicified listvenite with } \\
\text { disseminated mineralization }\end{array}$ & Qz, Carb, Gn & $\begin{array}{l}\text { Ttr, Bou, Ssy, Gdf, Nc, } \\
\text { Ull, Bhp }\end{array}$ \\
\hline \multirow{2}{*}{ 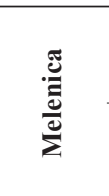 } & M1_1 & Listvenite outcrop & $\begin{array}{l}\text { Strongly silicified } \\
\text { listvenite with disseminated } \\
\text { mineralization }\end{array}$ & $\begin{array}{l}\text { Qz, Fe-Mn } \\
\quad \text { Carb }\end{array}$ & $\begin{array}{c}\text { Py, Mrc, Gn, Sp, Ccp, } \\
\text { Apy, Gdf, Seg, Mlr, Vio, } \\
\text { Brv }\end{array}$ \\
\hline & M1_8 & Listvenite outcrop & $\begin{array}{l}\text { Strongly silicified } \\
\text { listvenite with disseminated } \\
\text { mineralization }\end{array}$ & $\begin{array}{l}\text { Qz, Fe-Mn } \\
\quad \text { Carb }\end{array}$ & $\begin{array}{l}\text { Py, Mrc, Sp, Ccp, Gn, } \\
\text { Mlr, Gdf, Vio, Ull }\end{array}$ \\
\hline \multirow{2}{*}{$\frac{\sigma}{\stackrel{\Xi}{N}}$} & $\mathrm{~K} \_2 / 4$ & $\begin{array}{l}\text { Outcrop of massive carbonate-sulfide } \\
\text { orebody }\end{array}$ & $\begin{array}{l}\text { Massive - stratified } \\
\text { carbonate-sulfide vein }\end{array}$ & $\begin{array}{l}\text { Fe-Mn Carb, } \\
\text { Apy, Gdf, Bin }\end{array}$ & Ttr, Py, Gn, Ccp, Sp \\
\hline & $\mathrm{K} \_2 / 9$ & $\begin{array}{l}\text { Outcrop of massive carbonate-sulfide } \\
\text { orebody }\end{array}$ & $\begin{array}{l}\text { Massive carbonate veins } \\
\text { with sulfide veinlets }\end{array}$ & $\begin{array}{l}\text { Fe-Mn Carb, } \\
\text { Py, Apy, Gdf }\end{array}$ & Ttr, Ccp, Py, Sp \\
\hline
\end{tabular}

Apy - arsenopyrite; Bhp - breithauptite; Bin - bismuthinite; Bou - boulangerite; Brt - baryte; Brv - bravoite; Cal - calcite; Carb - Carbonates Ccp - chalcopyrite; Chr - chromite; Cv - covellite; Dol - dolomite; Gdf - gersdorffite; Gn - galena; Hem - hematite; Lö - löllingite; Mag magnetite; Mgs - magnesite; Mlr - millerite; Mrc - marcasite; Muc - maucherite; Nc - nickeline; Pld - polydymite; Pn - pentlandite; Py - pyrite; Pyh - pyrrhotite; Qz - quartz; Rmb - rammelsbergite; Seg - siegenite; Sp - sphalerite; Ssy - semseyite; Ttr - tetrahedrite group minerals; Ull - ullmannite; Vio - violarite

sphalerite, pyrite and chalcopyrite. Rarely, tetrahedrite, various $\mathrm{Bi}$ sulfosalts, $\mathrm{Pb}-\mathrm{Sb}$ sulfosalts, arsenopyrite, marcasite and Ni minerals were observed. Disseminated sulfide mineralization in listvenites is mainly formed by pyrite and arsenopyrite with minor galena, gersdorffite and other Ni minerals. A brief description of the samples containing GUS members used for geochemical studies is shown in Tab 1.

\subsection{Kizhnica-Badovc}

Representative samples from the Kizhnica-Badovc area were collected from the old dumps and listvenite outcrops on the transitional contact of serpentinites and andesites. Various ore types (massive - vein - banded ore and listvenite disseminated type of ore) can be found here. Massive ore with base metal mineralization consists of $\mathrm{Fe}-\mathrm{Mn}$ carbonates, quartz, sphalerite, galena, $\mathrm{Pb}-\mathrm{Sb}$ sulfosalts (boulangerite, semseyite, chovanite and jamesonite), pyrite, marcasite, stibnite and berthierite (Mederski et al. 2019). The $\mathrm{Pb}-\mathrm{Zn}-\mathrm{Sb}-\mathrm{Ni}$ mineralization forms veinlets, lenses and disseminations in listvenite (Fig. 3a, b). It consists of $\mathrm{Fe}-\mathrm{Mn}$ carbonates and quartz with sphalerite, galena, pyrite, chalcopyrite, tetrahedrite, GUS members (gersdorffite, Sb-rich gersdorffite and ullmannite), $\mathrm{Pb}-\mathrm{Sb}$ sulfosalts (boulangerite and semseyite), with minor arsenopyrite, pyrrhotite, hematite, chromite, native gold, nickel sulfides (millerite and pentlandite) and nickel thiospinels (polydymite and violarite) (Mederski et al. 2019) (Fig. 4a, b). Individual ore samples differ mainly in $\mathrm{Pb}-\mathrm{Zn}-\mathrm{Sb}$ mineralization grades. Seven samples containing GUS members from all 45 investigated samples from this locality were selected for EPMA analyses.

\subsection{Melenica}

Samples from Melenica were collected from a $20 \mathrm{~m} \times 50 \mathrm{~m}$ outcrop of hydrothermally altered rocks. The mineralization was formed on the contact of Jurassic basalts with the Miocene andesites. Listvenites from Melenica are highly silicified and are characterized by low-grade basemetal mineralization. At Melenica, sulfide mineralization is common in the form of dissemination and veinlets in the greenish listvenite. Listvenite-hosted ores consist 

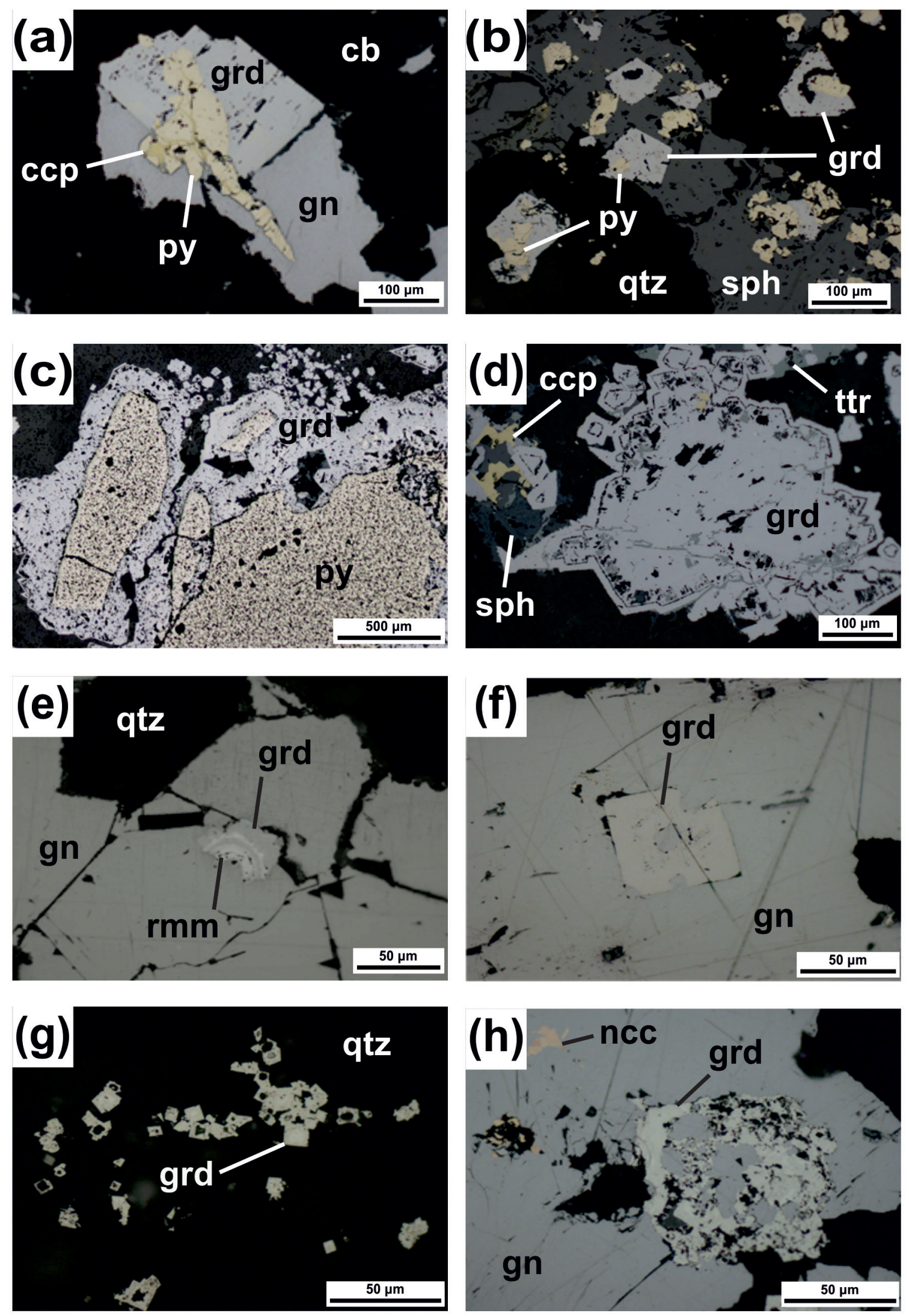
of quartz, Fe-Mn carbonates, pyrite, marcasite, galena, sphalerite, chalcopyrite, tetrahedrite, bournonite and minor Ni mineralization: GUS members (gersdorffite, Sb-rich gersdorffite and ullmannite), millerite, siegenite and violarite (Bal et al. 2019; Wojsław et al. 2019). Baryte veinlets are younger than those mentioned above. Two samples from 8 investigated listvenites from Melenica were selected for EPMA analyses.

\subsection{Mazhiq}

Samples from Mazhiq were collected along a mineralized body over a distance of $900 \mathrm{~m}$ on the contact of serpentinites or phyllites with volcanic rocks as well as from the surrounding listvenites. Samples are either massive, from the vein-type of mineralization, or disseminated, collected from the highly silicified rocks. Listvenitehosted ores are silicified and characterized by the presence of disseminated pyrite crystals and aggregates of arsenopyrite, chalcopyrite, galena, pyrite, sphalerite, tetrahedrite. Massive ore consists of $\mathrm{Fe}-\mathrm{Mn}$ carbonates, quartz, massive aggregates of pyrite, arsenopyrite, gersdorffite, needle-like crystals of Bi sulfosalts: bismuthinite and cosalite; galena, sphalerite and minor chalcopyrite, marcasite, tetrahedrite and native gold (Fig. 4c, d) (Bal et al. 2019; Wojsław et al. 2019; Węgrzynowicz et al. 2019). Two samples containing GUS members from all 17 investigated samples from Mazhiq were selected for EPMA analyses.

\subsection{VIlahia VL4 + VLX}

Samples from Vllahia were collected from two outcrops with macroscopically visible mineralization. The first one is gossan VL4 which was formed on listvenite at the contact of serpentinite and volcanic rocks. It is characterized by the presence of rare relics of base metal + nickel minerals. Only two samples with visible mineralization

Fig. 4 - Reflected-light images presenting textures of gersdorffite and associated assemblage of $\mathrm{Ni}-\mathrm{As}-\mathrm{Sb}-\mathrm{S}(\mathrm{Pb}-\mathrm{Zn}-\mathrm{Cu})$ within Trepça Mineral Belt. $\mathbf{a}-$ An aggregate consisting galena and gersdorffite with pyrite and chalcopyrite crystallizing along a fracture (Kizhnica - KZH6_4). b - Gersdorffite with pyrite in sphalerite I (Fe-rich) and sphalerite II (Kizhnica - SHA02_02a_4). c-Gersdorffite rimming anhedral pyrite (Mazhiq-K_2/9). d - Gersdorffite aggregate with tetrahedrite accompanied by chalcopyrite and sphalerite (Mazhiq - K_2/9). e - Banded aggregate composed of gersdorffite and rammelsbergite embedded in galena (Vllahia VLX - VLX_11_2). f - Caries texture of cubic crystal of gersdorffite - replacement of the core and corners of gersdorffite by galena (Vllahia VL4 - VL4_1). g - Euhedral crystals of gersdorffite disseminated in quartz (Vllahia VL4 - VL4_1). h - Strongly corroded aggregate of gersdorffite overgrown by galena (Vllahia VL4 - VL4_1). Ccp - chalcopyrite, Gn - galena, Gdf - gersdorffite, Nc - nickeline, Py - pyrite, Qz - quartz, Rmb - rammelsbergite, Sp - sphalerite, Ttr - tetrahedrite.
}

in typical listvenite rocks were found there. The secondplace VLX is a tectonic zone with hydrothermal massive sulfide vein on the contact of volcanic rocks and serpentinites. The mineral association contains galena, gersdorffite, millerite, pyrite, violarite, chalcopyrite, tetrahedrite, sphalerite, marcasite and rammelsbergite (Fig. 4e). Listvenite in gossan is rich in $\mathrm{Ni}$ mineralization and mineral association contain galena, tetrahedrite, $\mathrm{Pb}$ - $\mathrm{Sb}$ sulfosalts (semseyite, boulangerite and chovanite), sphalerite, gersdorffite-ullmannite, löllingite and Sb-bearing löllingite, rammelsbergite and $\mathrm{Sb}$-bearing rammelsbergite, nickeline and breithauptite (Fig. 4f-h) (Bal et al. 2019; Wojsław et al. 2019; Węgrzynowicz et al. 2019). Four samples containing GUS members from all 20 investigated samples from both localities were selected for EPMA analyses.

\subsection{Selac}

The samples from Selac were collected from a mineralized tectonic zone in a serpentinite outcrop. Most of the nickel mineralization in Selac is hosted by veinlets and small lenses within dolomite veins up to $1 \mathrm{~m}$ in thickness. Additionally, disseminated mineralization is visible in the surrounding silicified and carbonatized serpentinites. The main gangue minerals here are dolomite, quartz, as well as magnesite and fuchsite. Mineralized zones consist of galena, sphalerite, nickeline, maucherite, gersdorffite, rammelsbergite, polydymite, marcasite, pyrite, millerite and chromite (Bal et al. 2019). In addition, the presence of $\mathrm{Ni}$ mineralization with a higher proportion of basemetal minerals is observed on the prolongation of the tectonic zone: galena, sphalerite, pyrite, arsenopyrite, marcasite, tetrahedrite with minor Ni phases: nickeline and gersdorffite. One sample from 10 investigated mineralized rocks from Selac was selected for EPMA analyses.

\section{Results}

Representative results of the chemical analyses of GUS members from each locality are shown in the supplementary electronic table. Additionally, average EPMA data are presented in Tab 2.

\subsection{Kizhnica-Badovc}

Members of GUS from the Kizhnica area occur as disseminated separate euhedral or subhedral crystals up to $150 \mu \mathrm{m}$ as well as aggregates with galena and nickel minerals (Fig. 4a). Additionally, these crystals often occur as numerous accumulations at the edges of galena and sphalerite aggregates (Fig. 4b). Some of the gersdorffite crystals show patchy zonation (Fig. 5a). Other crystals are characterized by typical oscilla- 


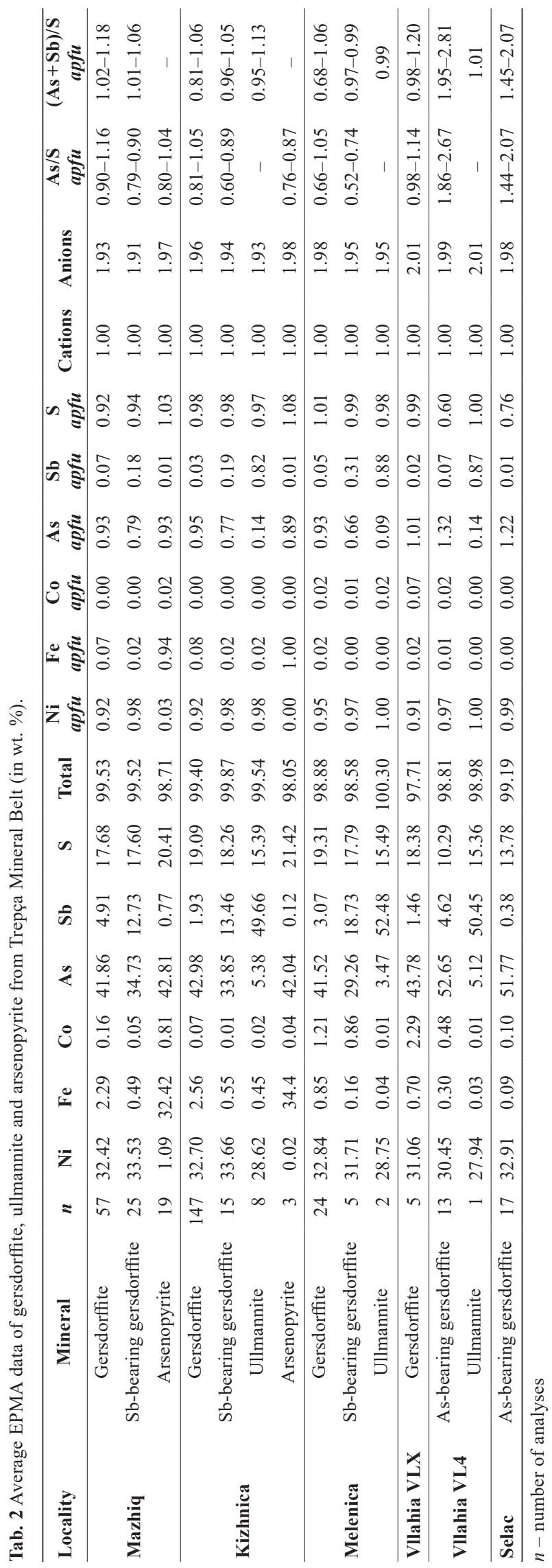

tory zonation (Fig. 5b). Dissolution and replacement of some GUS zones by younger hydrothermal galena and quartz are common (Fig. 5c,d). Corroded rounded pyrite crystals sometimes form the cores of gersdorffite aggregates (Fig. 4b; 5e). This pyrite is enriched in Co (up to 4 wt. \%) and $\mathrm{Ni}$ (up to $2.4 \mathrm{wt}$ \%). Gersdorffite end-member compositions are the most widespread in the Kizhnica GUS population. Gersdorffite composition from this site can be expressed by the formula $\left(\mathrm{Ni}_{0.66-0.99} \mathrm{Fe}_{0.01-0.32} \mathrm{Co}_{0.00-0.02}\right)_{\Sigma 1}\left(\mathrm{As}_{0.84-1.04} \mathrm{Sb}_{0.00-0.09}\right)_{\Sigma 0.95-1.03}$ $\mathrm{S}_{0.87-1.15}$ (Tab. 2). Two types of substitution can be observed: As-Sb, as well as $\mathrm{Ni}-\mathrm{Fe}$. The first one is manifested by the variable $\mathrm{As}-\mathrm{Sb}$ content, from low to those belonging to ullmannite (Fig. 7a). The formula of Sb-rich gersdorffite can be expressed as $\left(\mathrm{Ni}_{0.95-1.00} \mathrm{Fe}_{0.00-0.05}\right)_{\Sigma 1}$ $\left(\mathrm{As}_{0.59-0.86} \mathrm{Sb}_{0.10-0.42}\right)_{\Sigma 0.99-1.01} \mathrm{~S}_{0.88-1.00}$, and that of ullmannite as $\left(\mathrm{Ni}_{0.93-1.00} \mathrm{Fe}_{0.00-0.27}\right)_{\Sigma 1}\left(\mathrm{Sb}_{0.78-0.87} \mathrm{As}_{0.10-0.17}\right)_{\Sigma 0.92-0.99} \mathrm{~S}_{0.88-1.00}$. Most of the measurements of Sb-rich gersdorffite were carried out within the oscillatory zoned crystals (Fig. 5b). One of the GUS aggregate from the quartz-galena breccia is characterized by the presence of a zoned aggregate composed of GUS end members, as well as Sb-bearing gersdorffite (Fig. 5e). The crystallization sequence in this case is: gersdorffite I $>$ ullmannite $>$ Sb-enriched gersdorffite $>$ gersdorffite II. The contact between the earlier gersdorffite and ullmannite is sharp, while that between ullmannite and later gersdorffite shows gradual transition or fluctuations. The Ni-Fe substitution (Fig. 8) is caused by secondary enrichment related to the migration of younger fluids, responsible for base-metal mineralization and observed within the irregular zones often near crystal cracks (Fig. 5a,b). Therefore, the most Fe-enriched gersdorffite is Sb-poor and is found within the highest-grade listvenite-type $\mathrm{Pb}-\mathrm{Zn}$ ore. Gersdorffite is mostly $\mathrm{Fe}$ - and Co-poor. Arsenopyrite from the Kizhnica area occurs as euhedral crystals with sizes up to $200 \mu \mathrm{m}$ in the quartz-sphalerite breccia. The formula for arsenopyrite is $\mathrm{Fe}\left(\mathrm{As}_{0.82-0.93} \mathrm{Sb}_{0.00-0.02}\right)_{\Sigma 0.84-0.93} \mathrm{~S}_{1.07-1.11}$ (Tab. 2). Arsenopyrite is enriched in S (1.07-1.11 apfu)

Fig. 5 - Back-scattered-electron (BSE) images of gersdorffite from Kizhnica (a-e) and Melenica (f-h). a - Irregular crystal of gersdorffite with zones of different composition (SHA02_02a_2). $\mathbf{b}-$ Sb-rich zoned gersdorffite crystal (SHA02_02a_1). c - Zoned gersdorffite with dissolved zones and replaced by galena, sphalerite (KZH2_12). d - Galena replacing cores and edges of cubes of gersdorffite and sphalerite (KZH2_12). e - Aggregate composed of gersdorffite in the core, ullmannite in the center and transition Sb-bearing gersdorffite at the contact between ullmannite and external gersdorffite; galena and pyrite (KZH2_6). $\mathbf{f}$ - Euhedral violarite within needle-like millerite replaced by gersdorffite (Melenica - M1_8). g - Irregular aggregate composed of siegenite, chalcopyrite, GUS and galena (Melenica - M1_1). h Anhedral crystal of siegenite replaced by gersdorffite with the zone enriched in Sb with galena (Melenica - M1_1). Ccp - chalcopyrite, Carb - carbonates, Gn - galena, Gdf - gersdorffite, Mlr - millerite, Py pyrite, Seg - siegenite, Sp - sphalerite, Ull - ullmannite, Vio - violarite. 

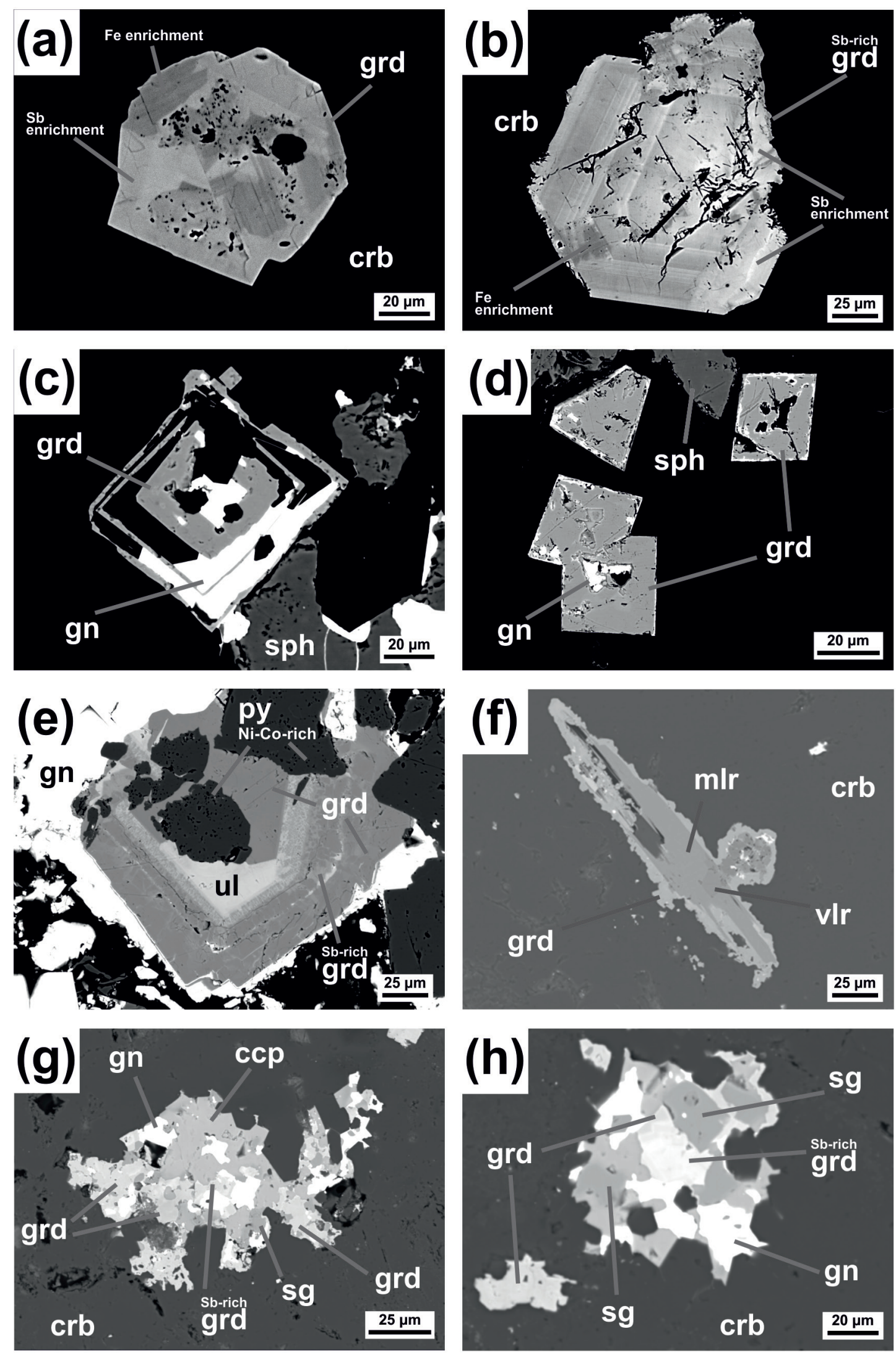

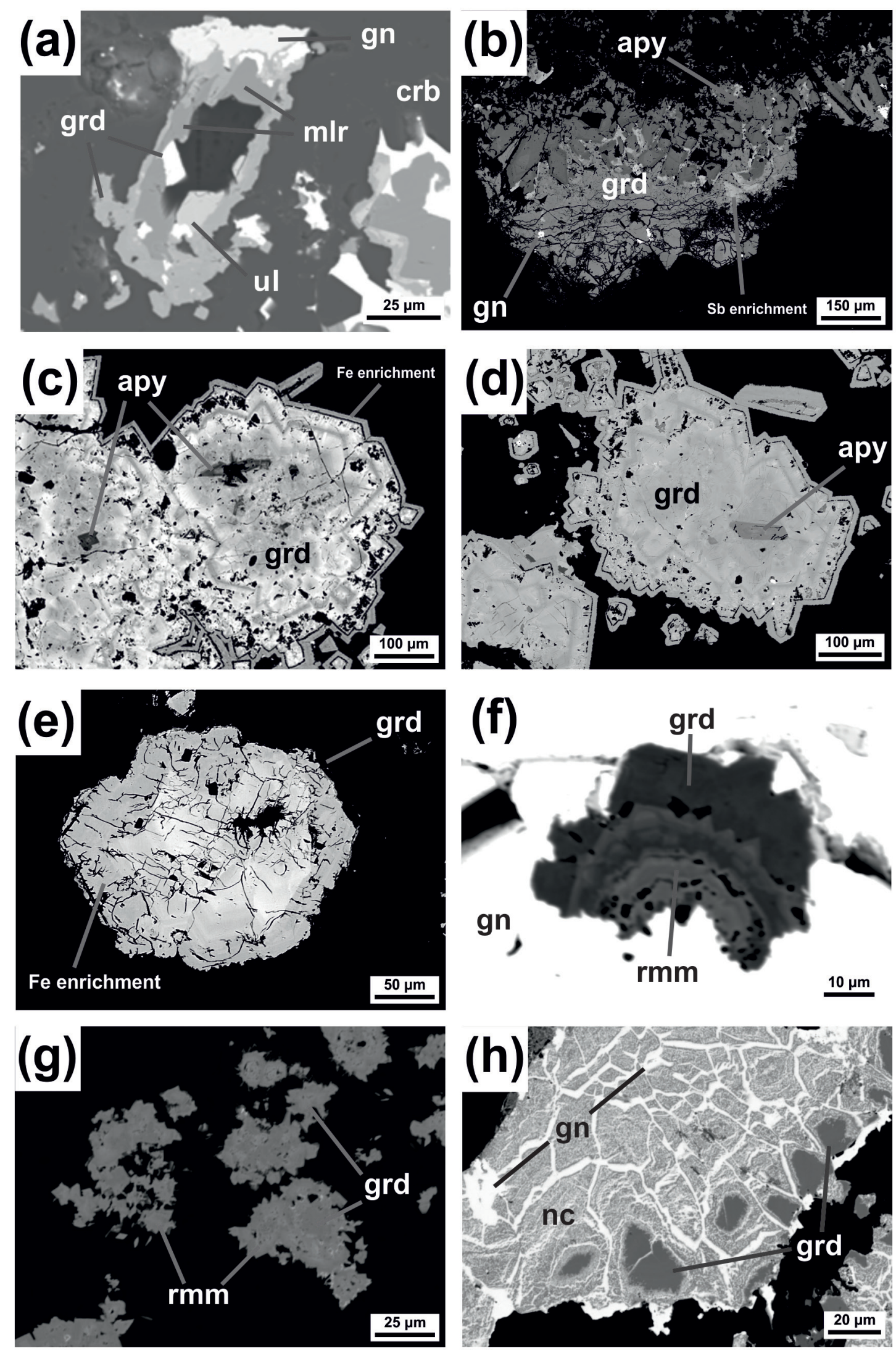

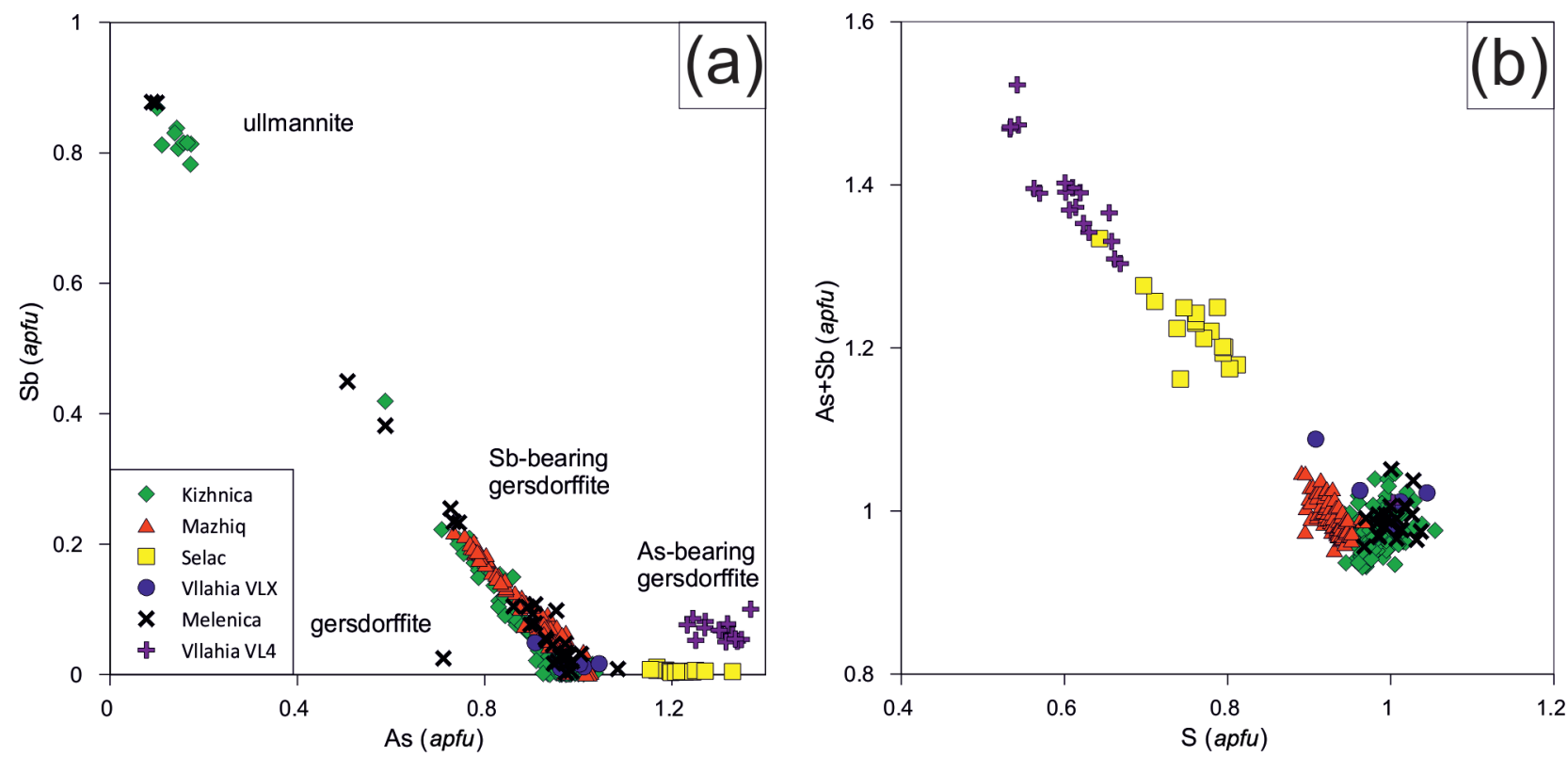

Fig. 7a - Correlations of gersdorffite from Trepça Mineral Belt between Sb vs. As. b - Correlations of gersdorffite from Trepça Mineral Belt between $\mathrm{Sb}+\mathrm{As} v s$. $\mathrm{S}$.

and depleted in As (0.82-0.93 apfu). Limited As-S substitutions were observed, and the As/S ratio is $0.8-1.05$ in gersdorffite, $0.60-0.89$ in Sb-bearing gersdorffite and $0.76-0.87$ in arsenopyrite.

\subsection{Melenica}

The gersdorffite in the Melenica samples is disseminated in listvenites and hard to identify by reflected-light microscopy due to the small crystal size (up to $20 \mu \mathrm{m}$ ). The Melenica GUS members occur as anhedral aggregates together with millerite, violarite and siegenite. GUS members are frequently replacing the boundaries of $\mathrm{Ni}-\mathrm{Co}$ sulfide crystals and are replaced by younger $\mathrm{Pb}-\mathrm{Zn}-\mathrm{Cu}$ sulfide minerals (Fig. 5f,g,h; 6a). Chemi-

Fig. 6 - Back-scattered-electron (BSE) images of gersdorffite from Trepça Mineral Belt. a - Anhedral aggregate of millerite being replacing by GUS and later overgrown by galena (Melenica - M1_8). b - Fractured gersdorffite with galena overgrown by arsenopyrite with zones of Sb-enrichment (K2_4). c - Oscillatory-zoned crystals of gersdorffite with visible bands related to variable content of As-Sb with an outer rim enriched in Fe and arsenopyrite (K2_9). d - Zoned crystal of gersdorffite with arsenopyrite as a core (K2_9). e - Zoned subhedral crystal of gersdorffite (Mazhiq - K2 4). f - Irregular banded aggregate of rammelsbergite in the centre and gersdorffite in outer rim (Vllahia VLX-VLX_11_2). g-Aggregates composed of euhedral rammelsbergite with gersdorffite filling interspaces (Vllahia VL4-VL4_1B). $\mathbf{h}-$ Remnants of gersdorffite in nickeline with a well-developed network of galena (Selac - T95_P04). Apy - arsenopyrite, Ccp - chalcopyrite, Carb - carbonates, $\mathrm{Gn}$ - galena, Gdf - gersdorffite, Mlr - millerite, $\mathrm{Nc}$ - nickeline, Py - pyrite, Rmb - rammelsbergite, Seg - siegenite, $\mathrm{Sp}$ - sphalerite, Ull - ullmannite. cal analyses identified a gersdorffite-ullmannite series (Fig. 7a). The average chemical formulae of individual GUS populations divided by their $\mathrm{As} /(\mathrm{As}+\mathrm{Sb})$ ratios can be presented as: $\left(\mathrm{Ni}_{0.73-0.99} \mathrm{Co}_{0.00-0.21} \mathrm{Fe}_{0.00-0.06}\right)_{\Sigma 1.00}\left(\mathrm{As}_{0.71-1.08}\right.$ $\left.\mathrm{Sb}_{0.00-0.11}\right)_{\Sigma 0.74-1.09} \mathrm{~S}_{0.97-1.09}$ for gersdorffite, $\left(\mathrm{Ni}_{0.94-0.99} \mathrm{Co}_{0.00-0.05}\right.$ $\left.\mathrm{Fe}_{0.0-0.01}\right)_{\sum 1.00}\left(\mathrm{As}_{0.51-0.74} \mathrm{Sb}_{0.23-0.45}\right)_{\sum 0.96-0.98} \mathrm{~S}_{0.97-1.01}$ for Sb-bearing gersdorffite and $\mathrm{Ni}\left(\mathrm{Sb}_{0.88} \mathrm{As}_{0.09-0.1}\right)_{\text {¿0.97-0.98 }} \mathrm{S}_{0.98-0.99}$ for ullmannite (Tab. 2). The measured Co concentrations in gersdorffite are the highest within the Trepça Belt (Fig. 8). The Sb-rich gersdorffite and ullmannite are characterized by low $\mathrm{Co}$ and $\mathrm{Fe}$ contents. The chemical data indicate limited cation substitution with the increasing $\mathrm{Sb}$ content. Sb-rich GUS and ullmannite are intergrown with the As-end member gersdorffite and are related to the irregular Sb-rich zones. Limited As-S substitution was observed; the As/S ratio of gersdorffite is $0.66-1.05$ and in Sb-bearing gersdorffite 0.52-0.74.

\subsection{Mazhiq}

In Mazhiq, gersdorffite is one of the main ore minerals with crystals up to a few $\mathrm{mm}$ in size. It occurs as a) irregular masses rimming crystals of arsenopyrite, pyrite I, or pyrite II (Fig. 4c; 6b) and b) intergrowth of euhedral to subhedral crystals with oscillatory zoning (Fig. 4d; $6 \mathrm{c}-\mathrm{e})$. Tetrahedrite often replaces or fills up cracks or crystallizes parallel to bands within the zoned gersdorffite crystals (Fig. 4d). Gersdorffite is often fractured parallel to ore zonation and is commonly porous, especially in the outer parts of crystals. Free spaces between consecutive gersdorffite generations are filled with quartz (Fig. 6c). 


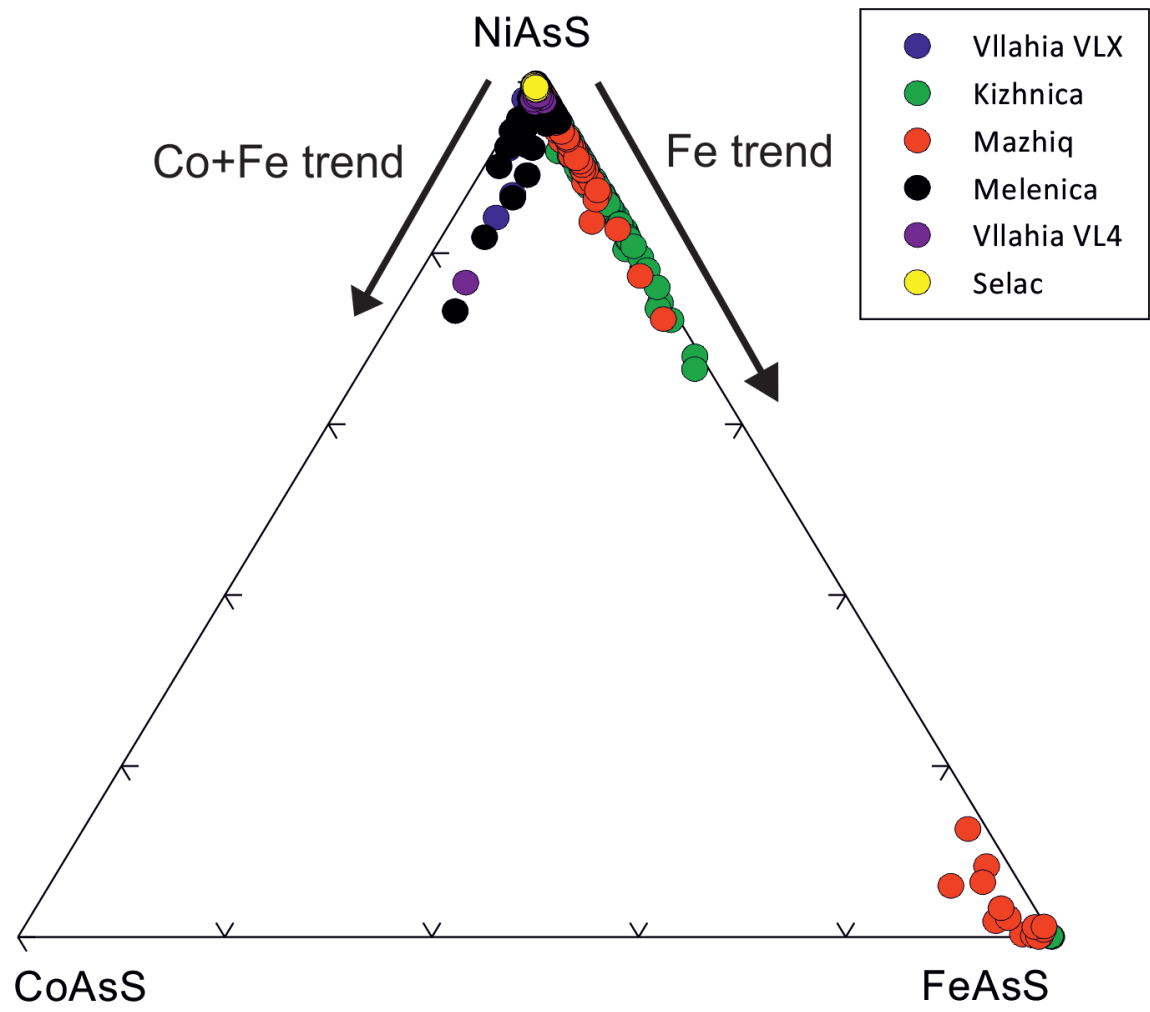

Fig. 8 - Composition of gersdorffite and arsenopyrite from Trepça Mineral Belt in ternary NiAsS-CoAsS-FeAsS system.
Arsenopyrite is often found in oscillatory zoned gersdorffite and forms a sharp boundary with its host (Fig. 6c, d). Moreover, arsenopyrite that is crystallized in open cavities appears as euhedral crystals up to $500 \mu \mathrm{m}$ in size, commonly showing corroded boundaries, overgrown by gersdorffite and $\mathrm{Sb}$-rich gersdorffite. BSE images show zonation caused by enrichment in Fe as well as the As-Sb substitution (Fig. 6c-e). The average formula of gersdorffite is $\left(\mathrm{Ni}_{0.77-0.99} \mathrm{Fe}_{0.00-0.26} \mathrm{Co}_{0.00-0.03}\right)_{\sum 1.00}\left(\mathrm{As}_{0.84-1.03}\right.$ $\left.\mathrm{Sb}_{0.00-0.14}\right)_{\Sigma 0.96-1.05} \mathrm{~S}_{0.89-0.97}$ (Tab. 2). On the cation position, only Fe-Ni substitution is observed (Fig. 8). Gersdorffite enriched in Fe usually composes the outer part of the zoned crystals and is assumed to be formed by late fluids responsible for the base-metal mineralization (Fig. 6c). An intermediate As-Sb member, with the composition $\left(\mathrm{Ni}_{0.96-0.99} \mathrm{Fe}_{0.00-0.03}\right)_{\sum 1.00}\left(\mathrm{As}_{0.73-0.84} \mathrm{Sb}_{0.14-0.22}\right)_{\sum 0.95-0.99} \mathrm{~S}_{0.93-0.95}$, was found as zones within inner, non-porous part of oscillatory zoned GUS aggregates (Fig. 6c, d). Sb-bearing gersdorffite tends to be $\mathrm{Fe}$ - and Co-poor. On the ternary diagram of the system $\mathrm{Ni}-\mathrm{Co}-\mathrm{Fe}$, gersdorffite extends directly towards arsenopyrite composition (Fe trend). However, there is a miscibility gap (Fig. 8). Gersdorffite from this site has the highest content of Fe (0.26 apfu) among the occurrences from the Trepça Mineral Belt. The As/S ratio is $0.90-1.16$ in gersdorffite and $0.78-0.9$ in Sb-bearing gersdorffite. The formula for arsenopyrite from Mazhiq is $\left(\mathrm{Fe}_{0.85-0.98} \mathrm{Ni}_{0.00-0.13} \mathrm{Co}_{0.00-0.07}\right)_{\sum 1.00}\left(\mathrm{As}_{0.87-0.99}\right.$ $\left.\mathrm{Sb}_{0.00-0.02}\right)_{\sum 0.89-1} \mathrm{~S}_{0.95-1.07}$ (Tab. 2), with only slight Ni and Co enrichment. Arsenopyrite occurs as tiny core crystals (up to $10 \mu \mathrm{m}$ ) within oscillatory zoned gersdorffite crystals (Fig. 6d) or as euhedral crystals (up to $30 \mu \mathrm{m}$ ) overgrowing masses of GUS (Fig. 6b). Moreover, it is associated with chalcopyrite and pyrite and is often replaced by sulfosalts.

\subsection{VIlahia (VIx)}

Gersdorffite occurs here as tiny (up to $20 \mu \mathrm{m}$ in size) anhedral to subhedral crystals or aggregates together with rammelsbergite, all enclosed in galena. Gersdorffite frequently replaces rammelsbergite and may form horseshoe-shaped zonal aggregates (Fig. 4e; 6f). The formula of gersdorffite from Vllahia can be expressed as $\left(\mathrm{Ni}_{0.84-0.98}\right.$ $\left.\mathrm{Co}_{0.02-0.12} \mathrm{Fe}_{0.00-0.04}\right)_{\sum 1.00}\left(\mathrm{As}_{0.97-1.04} \mathrm{Sb}_{0.01-0.05}\right)_{\sum 0.98-1.09} \mathrm{~S}_{0.91-1.04}$ (Tab. 2). The chemical composition of gersdorffite from Vllahia is nearly stoichiometric, with only a slight Co enrichment (Fig. 8).

\subsection{Vllahia (VI4) gossan}

Gersdorffite forms subhedral to euhedral intergrowths up to $50 \mu \mathrm{m}$ in size and is overgrown by younger galena and $\mathrm{Pb}-\mathrm{Sb}$ sulfosalts (Fig. 4f, h) or occurs as aggregates together with rammelsbergite disseminated in silicified listvenite (Fig. 6g). Gersdorffite edges and cores are 

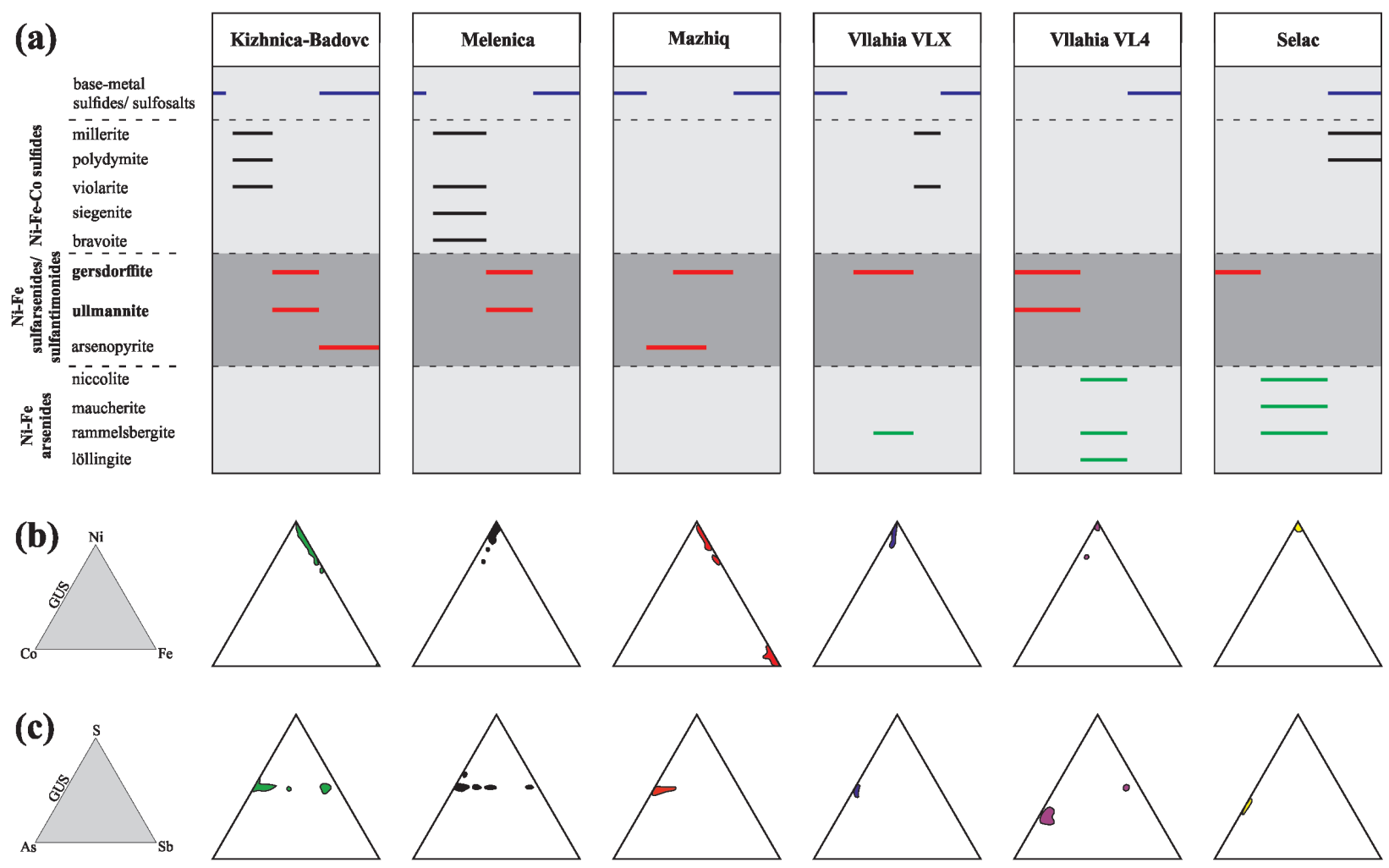

Fig. 9a - Paragenetic position of GUS from Trepça Mineral Belt. b - Ternary diagram Ni vs. Co vs. Fe of the GUS from TMB. $\mathbf{c}-$ Ternary diagram As vs. Sb vs. S of the GUS from TMB.

frequently corroded and replaced by quartz, galena, pyrite, or $\mathrm{Pb}-\mathrm{Sb}$ sulfosalts (Fig. 4h). This phenomenon led to the development of skeletal textures, i.e., caries texture (Fig. 4f) and atoll texture (Fig. 4g). Gersdorffite is associated together with rammelsbergite, löllingite, Sb-bearing löllingite, breithauptite and ullmannite. The chemical composition of gersdorffite can be expressed as $\left(\mathrm{Ni}_{0.95-0.99} \mathrm{Co}_{0.00-0.03} \mathrm{Fe}_{0.00-0.04}\right)_{\sum 1.00}\left(\mathrm{As}_{1.23-1.43} \mathrm{Sb}_{0.04-0.15}\right)_{\sum 1.30-1.52}$ $\mathrm{S}_{0.53-0.67}$ (Tab. 2). The substitution is limited at the cation position. On the other hand, gersdorffite is enriched in As (1.23-1.67 apfu) and depleted in S (0.32-0.68 apfu) in comparison with stoichiometric gersdorffite (Fig. 7a, b). The Vllahia (VL4) gersdorffite represents the Asrichest composition within the Trepça Belt, approaching rammelsbergite/krutovite (Fig. 7a, b). The As/S ratio varies from 1.86 to 2.67. Chemical analyses (EPMA) identified one ullmannite crystal with the composition $\mathrm{Ni}\left(\mathrm{Sb}_{0.87} \mathrm{As}_{0.14}\right)_{\sum 1.01}$ S. Ullmannite associates with breithauptite and is enclosed in galena.

\subsection{Selac}

Gersdorffite is a minor constituent, occurring as small residues (up to $40 \mu \mathrm{m}$ in size) within masses of nickeline. All fractures and fissures are healed by galena (Fig. 6h).
Polymineral aggregates are corroded, possess cellular textures and are indicative of the high intensity of replacement processes (Fig. 6h). Gersdorffite from Selac is associated with sphalerite and tennantite and has the composition $\mathrm{Ni}\left(\mathrm{As}_{1.33-1.15} \mathrm{Sb}_{0.01-0.00}\right)_{\Sigma 1.33-1.18} \mathrm{~S}_{0.81-0.64}$ (Tab. 2). It is characterized by stoichiometric content of $\mathrm{Ni}$, significant enrichment of As (1.15-1.33 apfu) and depletion of S (0.64-0.81 apfu) (Fig. 7a, b). Gersdorffite from Selac, together with Vllahia VL4 has the As-richest composition among all localities. There is no correlation among cations and the ratio $\mathrm{As} / \mathrm{S}$ is 1.44 to 2.07, suggesting that As content is independent of the metal content.

\section{Discussion}

\subsection{Paragenetic position of gersdorffite}

Combined reflected-light microscopy observations and chemical analyses at a micro-scale revealed the presence of complex textures involving gersdorffite with variable compositions occurring in different mineral associations within the Trepça Mineral Belt (TMB). The generalized paragenetic position of gersdorffite in each locality, as well as $\mathrm{Ni}-\mathrm{Co}-\mathrm{Fe}$ and the As-Sb-S ternary diagrams of the GUS series are presented in Fig. 9. Based on the ob- 
tained results, the two main types of paragenetic sequence with nickel mineralization and GUS are distinguished.

The first one is characterized by crystallization of $\mathrm{Ni}$ sulfarsenides and sulfantimonides after $\mathrm{Ni}-\mathrm{Fe}-\mathrm{Co}$ sulfides (millerite, violarite, siegenite, polydymite and bravoite) precipitation and was observed in KizhnicaBadovc and Melenica localities. At Melenica, $\mathrm{Ni}-\mathrm{Co}-\mathrm{Fe}$ sulfides were transformed into GUS, which forms typical outer rims (Fig. 5f). Most GUS from Kizhnica occurs in the form of euhedral crystals, but rare mineral aggregates are observed, where it grows around earlier sulfides - millerite, polydymite and violarite. There are no Ni arsenides in the paragenetic sequence at these locations.

On the other hand, the Ni sulfarsenides from Vllahia (VLX and VL4) and Selac were formed before Ni-Fe arsenide and diarsenide (nickeline, rammelsbergite and maucherite) precipitation. However, sulfarsenides from Vllahia VL4 and Selac have a non-stoichiometric composition with As $>$ S. Gersdorffite from Selac is rare and forms residues after arsenides replacement (nickelinerammelsbergite-maucherite massive aggregates). Additionally, the replacement by rammelsbergite and löllingite is the characteristic feature for gersdorffite from Vllahia VL4. Sulfarsenides from Vllahia VL4 and Selac (with non-stoichiometric composition, where As $>$ S) seem to crystallize from primary, intermediate As-rich solution to become unstable and further replaced into arsenides, representing an environment with increasing As activity. The opposite trend was reported by Radosavljević et al. (2015) in Kaludjer from Rogozna Ore Field in Kosovo, where nickeline was replaced by sulfantimonides or sulfarsenides. Vllahia VLX confirms the trend described by Radosavljević et al. (2015), where the stoichiometric gersdorffite replaces rammelsbergite to form a banded aggregate, which suggests variable As activity. A transformation of arsenides to sulfarsenides was described in hydrothermal Ni-Co-Fe-As veins in Dobšiná (Kiefer et al. 2017) and the Zemberg-Terézia vein system near Dobšiná (Števko and Sejkora 2020). Additionally, paragenetic sequences from Vllahia VLX and Selac are characterized by the presence of Ni sulfides (millerite, polydymite and violarite) at the last stage of the Ni crystallization sequence.

However, gersdorffite is the only nickel phase in the paragenetic sequence of polymetallic $\mathrm{Cu}-\mathrm{Bi}-\mathrm{Ni}-\mathrm{Au}$ mineralization from Mazhiq. GUS does not coexist with both $\mathrm{Ni}-\mathrm{Co}-\mathrm{Fe}$ sulfides and arsenides. The co-existence of gersdorffite with hydrothermal $\mathrm{Bi}-\mathrm{Au}$ association is raised in a subsequent paragraph.

\subsection{Chemical composition of GUS}

Gersdorffite recognized at the studied localities within Trepça Mineral Belt comprises two populations concerning $\mathrm{As} / \mathrm{S}$ ratio, which is a hint of two different hydrother- mal fluids. The low As/S ratio of Kizhnica-Badovc (0.601.06), Mazhiq (0.79-1.16), Melenica (0.52-1.05), Vllahia (VLX) (0.98-1.14) indicate decreasing As concentrations in the hydrothermal fluids in relation to the fluids from Vllahia (VL4) (1.86-2.67) and Selac (1.44-2.07) (Tab. $2)$. The former localities are characterized by relatively homogenous compositions of gersdorffite in comparison to Vllahia (VL4) and Selac. This reveals the fluctuation of the compositions of the hydrothermal fluids during crystallization. Harms (2010) found more clear and distinguishable populations between post-Variscan vein deposits and strata-bound mineralization concerning the variability of As/S ratio and homogeneity of hydrothermal fluids.

However, a complete GUS solution (gersdorffite-ullmannite) is found in the Trepça Mineral Belt (Radosavljević et al. 2015; this study). Otherwise, Harms (2010) show only limited content of Sb up to 0.05 apfu. Stoichiometric ullmannite is rare in studied samples from TMB and is observed only in samples from Kizhnica-Badovc, Melenica and Vllahia VL4. Ullmannite was also described by Radosavljević et al. (2015) in the Rogozna Ore Field. Additionally, As-Sb substitution is observed within the oscillatory zoned crystals (Fig. 5b, e) from typical listvenite type of mineralization from Kizhnica, as well as in massive gersdorffite aggregates from Mazhiq. The majority of Sb-bearing gersdorffite in Mazhiq occurs within the inner part of crystals, which implies that As-Sb substitution is present mainly at an early stage, with an environment with a high $\mathrm{Sb}$ concentration. As-Sb exchange of gersdorffite-ullmannite solid solution is not continuous; there is a gap between ullmannite and Sb-bearing gersdorffite (Fig. 7a). Analogous behavior was reported by Radosavljević et al. (2015) and the opposite by Voudouris et al. (2018).

In addition to that, Harms (2010) gathered reliable evidence that a small extent of substitution on cation sites together with a narrow range of As/S ratio (0.88-1.01) of post-Variscan vein deposits imply thermochemical As reduction and mixing (homogenization) of the hydrothermal fluids leading to ore precipitation far away from the site of ore deposition. Meanwhile, the $\mathrm{Co}-\mathrm{Fe}$ trend and broader As/S ratio (1.06-1.21) in the strata-bound mineralization evoke the mixing of the hydrothermal fluids close to the site of ore deposition. It seems to be with disagreement with the data collected within the Trepça Mineral Belt, where only Kizhnica-Badovc and Mazhiq are assumed to occur in proximity to the site of ore deposition concerning an appearance as massive ore. The latter author also suggests that the variability in the As/S ratios could be a consequence of disequilibrium crystallization, which might be the case for Selac where the replacement process is well-developed. What is more, the relationship in Selac Ni-rich association might be regarding low-temperature re-equilibrium and replacement of preceding gersdorffite into nickeline, maucherite and rammelsbergite. 
Fig. 10 - Activity of $\log f\left(\mathrm{~S}_{2}\right)$ and temperature (T) projection of the stability field of arsenopyrite (after Kretschmar and Scott 1976, Sharp et al. 1985).

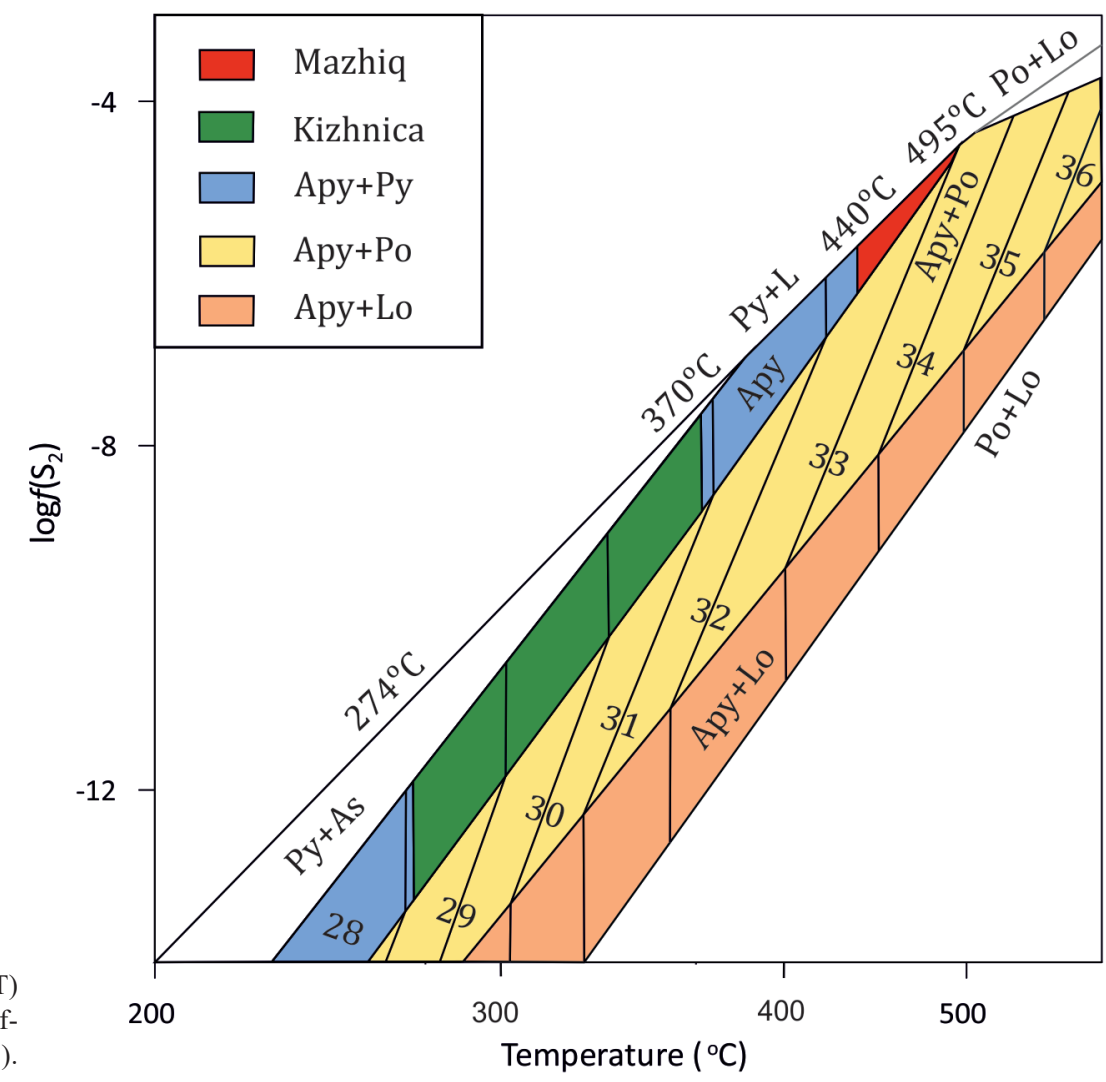

Hem and Makovicky 2004a, 2004b) have been done on dry systems with unrealistic temperatures encountered in hydrothermal conditions. Therefore, the geochemical data of other mineral phases (arsenopyrite and sphalerite) from studied occurrences were used to determine the formation conditions. An arsenopyrite geothermometer (Kretschmar and Scott 1976; Sharp et al. 1985) was used for listvenites from Mazhiq and Kizhnica-Badovc. The formation temperatures of sphalerite in Kizhnica were estimated based on a GGIMFis geothermometry (Frenzel et al. 2016).

Arsenopyrite is formed simultaneously with gersdorffite in Mazhiq samples as well as gersdorffite in Kizhnica. In both occurrences, arsenopyrite is found together with pyrite as the only sulfide phase. To estimate the formation temperature of arsenopyrite, the As content can be used (Kretschmar and Scott 1976; Sharp et al. 1985). Three out of 19 and 2 out of 3 chemical analyses of arsenopyrite from Mazhiq and Kizhnica, respectively, were selected, which satisfy the conditions: 1$) \mathrm{Ni}+\mathrm{Co}+\mathrm{Sb} \leq 1$ wt. $\%$, 2) the total does not deviate more than 2 wt. \% from 100 wt. \%. Thus, the As values of arsenopyrite fall in the "pyrite + arsenopyrite" zone of the buffered assemblages involving arsenopyrite in the $\mathrm{Fe}-\mathrm{As}-\mathrm{S}$ system.

The temperature is constrained from $440{ }^{\circ} \mathrm{C}$ to $495^{\circ} \mathrm{C}$ and -6 to $-4.5 \log f\left(\mathrm{~S}_{2}\right)$ for arsenopyrite from Mazhiq (Fig. 10). Arsenopyrite appears as the first phase together with gersdorffite and pyrite in the paragenetic sequence in 
Mazhiq. Temperatures obtained for arsenopyrite seem to be consistent with the fact that Mazhiq assemblage was formed close to the deposition site based on As/S ratio in gersdorffite. A similar range of formation temperatures $\left(400-450^{\circ} \mathrm{C}\right)$ of arsenopyrite was estimated by Voudouris et al. (2018) in the Clemence deposit from Kamariza Mining District in Greece. The authors suggest the possible overestimation of temperatures of arsenopyrite from the $\mathrm{Ni}-\mathrm{Bi}-\mathrm{Au}$ assemblage from the Clemence deposit by comparing the results from fluid inclusion studies.

On the other hand, the temperature is constrained from $274^{\circ} \mathrm{C}$ to $370^{\circ} \mathrm{C}$ and yielded -12 to $-8 \log f\left(\mathrm{~S}_{2}\right)$ for arsenopyrite from Kizhnica (Fig. 10). Measured arsenopyrite (sample KZH2 12) forms euhedral crystals which overgrow sphalerite aggregates. Additionally, GGIMFis geothermometry ("Ga, Ge, In, Mn and Fe in sphalerite") (Frenzel et al. 2016) was used to determine the crystallization temperature of the same sphalerite from the quartz-sphalerite breccia and it yielded temperatures from $330^{\circ} \mathrm{C}$ to $370^{\circ} \mathrm{C}$ (Mederski, unpublished). Therefore, it is assumed that arsenopyrite crystallizes with the decreasing temperatures of the hydrothermal fluids and is connected with the younger, base-metal stage of precipitation. Moreover, sphalerite from listvenites (e.g., samples SHA02_02) was formed at similar temperatures (340-390 $\left.{ }^{\circ} \mathrm{C}\right)$ (Mederski, unpublished). Comparable temperatures have been estimated for sphalerites coexisting with GUS from Rogozna Ore Field by Radosavljević et al. (2015). The crystallization temperature of the main sulfide association is estimated at $390-430^{\circ} \mathrm{C}$ (Crnac) and $305-440{ }^{\circ} \mathrm{C}$ (Plakaonica) (using the distribution of cadmium and manganese between coexisting galena and sphalerite) (Radosavljević et al. 2015).

\subsection{Bi mineralization related to GUS occurrences (post-Ni mineralization)}

The occurrence of GUS from Mazhiq is significantly different from other studied GUS locations from TMB, mainly due to the presence of bismuth sulfosalts (bismuthinite and cosalite) in post-Ni mineralization. The co-existence of the GUS, as well as the Bi minerals, is known for many locations in the Balkan area (Voudouris et al. 2008, 2018; Vavelidis and Melfos 2004; Tombros et al. 2007; Radosavljević et al. 2016). The $\mathrm{Cu}-\mathrm{Bi}-\mathrm{Ni}-\mathrm{Au}$ mineral assemblage occurring in Mazhiq shows many similarities with polymetallic $\mathrm{Ni}-\mathrm{Bi}-\mathrm{Au}$ assemblage from the Kamariza Mining District (Clemence Mine and "km3" locality) from the Lavrion ore field in Greece (Voudouris et al. 2008, 2018). Voudouris et al. (2018) described, e.g., pyrite, arsenopyrite, chalcopyrite, native $\mathrm{Au}$, bismuthinite, Ag-sulfosalts and oscillatory zoned GUS. The authors proposed a mixed hydrothermal-magmatic origin of the mineralization in the Kamariza region. Fur- thermore, the $\mathrm{Bi}-\mathrm{Ag}-\mathrm{Cu}$ Kapsalina occurrence in Thasos islands, Northern Greece with gersdorffite was described by Vavelidis and Melfos (2004). The $\mathrm{Bi}-\mathrm{Ag}-\mathrm{Cu}$ mineralization hosted in quartz veins consists of chalcopyrite, pyrite, bismuthinite, $\mathrm{Bi}-\mathrm{Ag}$ enriched tetrahedrite group minerals, and two types of gersdorffite (Fe-poor and Ferich). The $\mathrm{Ni}-\mathrm{Fe}$ substitution observed in gersdorffite from Kapsalina caused by secondary enrichment is a common feature for occurrences in Vardar Zone (Mazhiq and Kizhnica). In addition, as in Mazhiq, tetrahedrite replaced gersdorffite. On the other hand, the authors described in Kapsalina that crystallization of bismuthinite took place before gersdorffite, while in Mazhiq, bismuthinite crystallized during the last hydrothermal stage.

As mentioned above, the mineral association in Mazhiq is characterized by the presence of native $\mathrm{Au}$ and $\mathrm{Bi}$ sulfosalts (bismuthinite and cosalite). A similar $\mathrm{Bi}-\mathrm{Au}$ rich mineralization was reported from Stan Terg $\mathrm{Pb}-\mathrm{Zn}-\mathrm{Ag}$ deposit (Kołodziejczyk et al. 2015, 2017). Kołodziejczyk et al. $(2015,2017)$ described Bi-sulfotellurides associated with $\mathrm{Pb}-\mathrm{Bi}-\mathrm{Sb}$ sulfosalts and galena in pyrite-pyrrhotite-galena-rich, in both skarn and hydrothermal ore bodies. The Stan Terg association exhibits a lack of nickel minerals in the system. Moreover, on the east side of Mazhiq locality, the occurrence of Bi-Au rich ores (with Bi sulfosalts: cosalite, bismuthinite, aikinite; native $\mathrm{Bi}$ and native $\mathrm{Au}$; without Ni minerals) were reported (Mederski et al. 2018; Węgrzynowicz et al. 2019). Therefore, both Mazhiq localities could be assumed as an N-NE continuation of the $\mathrm{Bi}-\mathrm{Au}$ rich ore bodies of the Stan Terg hydrothermal system. However, within Kizhnica-Hajvalia-Badovc ore field, a similar $\mathrm{Bi}-\mathrm{Au}$ system is observed in the eastern part of the ore field, although it is not linked to listvenitization (Mederski, unpublished data).

Additionally, members of GUS are widespread within other types of polymetallic occurrences within the Balkan region, e.g., in Panormos Bay $\mathrm{Au}-\mathrm{Ag}-\mathrm{Te}$ mineralization (Tombros et al. 2007) or Čumavići $\mathrm{Sb}-\mathrm{Zn}-\mathrm{Pb}-\mathrm{Ag}$ deposit (Radosavljević et al. 2016), however, with no particular mineralogical studies about the geochemistry of gersdorffite.

\section{Conclusions}

The previously unknown Ni mineralization was described in hydrothermally altered serpentinites (listvenites) from the broad Stan Terg area and Kizhnica-Hajvalia-Badovc ore field from Trepça Mineral Belt. Gersdorffite is the dominant $\mathrm{Ni}$ phase in the Ni-As-Sb-S association (Kizhnica-Badovc, Mazhiq, Vllahia VLX, Vllahia VL4, except Melenica and Selac) and forms disseminated crystals or aggregates with other Ni phases and base metal sulfides in listvenite rocks. 
The two main types of paragenetic sequence with nickel mineralization and GUS are distinguished in TMB. The first one is characterized by the sequence: 1) $\mathrm{Ni}-\mathrm{Fe}-$ Co sulfides; 2) Ni-sulfarsenides and sulfantimonides; and is observed in Kizhnica-Badovc and Melenica. The second type of sequence includes 1) $\mathrm{Ni}$-sulfarsenides; 2) $\mathrm{Ni}-\mathrm{Fe}$ arsenide and diarsenide; 3) $\pm \mathrm{Ni}$ sulfides. Second type of sequence occurs in Vllahia VLX, Vllahia VL4 and Selac. However, gersdorffite is the only nickel phase in the paragenetic sequence from Mazhiq.

Gersdorffite recognized in surroundings of Stan Terg area and Kizhnica-Hajvalia-Badovc ore field is characterized by three substitutional trends: $\mathrm{Fe}+\mathrm{Co} / \mathrm{Ni}$ (all localities, except Selac); As/Sb (Kizhnica, Mazhiq, Vllahia $\mathrm{VLX}$ ) and $\mathrm{As}+\mathrm{Sb} / \mathrm{S}$ (Selac and Vllahia VL4). Variability among the cations, $\mathrm{As}-\mathrm{Sb}$, as well as $\mathrm{As}+\mathrm{Sb} / \mathrm{S}$, indicates the fluctuation of $\mathrm{As}, \mathrm{Sb}$ and $\mathrm{S}$ activity in hydrothermal fluids.

The As/S ratio differentiates two hydrothermal fluids: narrow range and low values (Kizhnica, Mazhiq, Melenica, Vllahia VLX) suggest depressed As activity, mixing in the proximity of deposition site (Kizhnica, Mazhiq), broad range and elevated values: increased As activity, more inhomogeneous fluids and disequilibrium crystallization (Selac, Vllahia VL4).

Acknowledgments. We are grateful to Adam Włodek and Gabriela Kozub-Budzyń from the Laboratory of Critical Elements at AGH-UST, Faculty of Geology, Geophysics and Environmental Protection, for help during EMPA data collection. Vasilios Melfos and the anonymous reviewer are acknowledged for their friendly and critical comments that helped significantly improve the manuscript. The research was funded by the Society of Economic Geologists Canada Foundation (SEGCF) Student Research Grant 2019 and AGH-UST 2018 Rector Grant assigned to the SKNG student grant.

Electronic supplementary material. Supplementary material providings details on representatives EPMA data of gersdorffite from Trepça Mineral Belt is available online at the Journal web site (http://dx.doi.org/10.3190/ jgeosci.322).

\section{References}

Ahmed AH, Arai S, Ikenne M (2009) Mineralogy and paragenesis of the $\mathrm{Co}-\mathrm{Ni}$ arsenide ores of Bou Azzer, Anti-Atlas, Morocco. Econ Geol 104(2): 249-266

Bal S, Pršek J, Mederski S, Asllani B, Wojnarowska A, CIEŚLAK A (2019) Nickel mineralization in hydrothermally altered serpentinites (listwaenites) in the broad area of Stan Terg mine, Vardar Zone, Kosovo. Proceedings of the Life with Ore Deposits on Earth: $15^{\text {th }}$ Biennial SGA Meeting, Glasgow, Scotland, August 27-30 2019; University of Glasgow Publicity Services: Glasgow, Scotland, 1: 384-387

BAYLISS P (1969) X-ray data, optical anisotropism, and thermal stability of cobaltite, gersdorffite, and ullmannite. Mineral Mag 37(285): 26-33

BAYLiss P (1982) A further crystal structure refinement of gersdorffite. Amer Miner 67: 1058-1064

BAYliss P, STEPHENSON NC (1967) The crystal structure of gersdorffite. Mineral Mag 36(277): 38-42

BAYLiss P, StePHENSON NC (1968) The crystal structure of gersdorffite (III), a distorted and disordered pyrite structure. Mineral Mag 36(283): 940-947

BeLKIN HE, Luo K (2008) Late-stage sulfides and sulfarsenides in Lower Cambrian black shale (stone coal) from the Huangjiawan mine, Guizhou Province, People's Republic of China. Mineral Petrol 92(3-4): 321-340

Borojevic Šoštarić SB, Palinkaš LA, Topa D, SpanGeNBerg JE, Prochaska W (2011). Silver-base metal epithermal vein and listwaenite types of deposit Crnac, Rogozna Mts., Kosovo. Part I: Ore mineral geochemistry and sulfur isotope study. Ore Geol Rev 40(1): 65-80

Borojevic Šoštarić SB, Palinkaš LA, Neubauer F, Hurai V, CVetković V, Roller-Lutz Z, Genser J (2013) Silver-base metal epithermal vein and listwanite hosted deposit Crnac, Rogozna Mts., Kosovo, part II: A link between magmatic rocks and epithermal mineralization. Ore Geol Rev 50: 98-117

CVetKović V, Šarić K, PéCSKay Z (2011) The Rudnik Mt. Volcanic and Metallogenetic Complex: an Example of $\mathrm{Pb}-\mathrm{Zn}$ Tertiary Deposit in the Central Balkan Peninsula. Annual of the Yugoslav Association of Mineralogy 3: $135-138$

DANGIĆ A (1993) Tetriary lead-zinc ore deposits and calcoalcaline magmatism of the serbo-macedonian province: metallogenic and geochemical characteristics, hydrothermal systems and their evolution. Geol An Balk Poluostrva (Ann Geol Penins Balk) 57(1): 257-285

EleZAJ Z (2009) Geodynamic evolution of Kosovo during the Triassic and Jurassic. J Earth Sci Application and Research Centre of Hacettepe University 30(2): 113-126

Emam A, Zoheir B (2013) Au and Cr mobilization through metasomatism: microchemical evidence from ore-bearing listvenite, South Eastern Desert of Egypt. J Geochem Explor 125: 34-45

Fanlo I, Subías I, Gervilla F, Paniagua A, García B (2004) The composition of $\mathrm{Co}-\mathrm{Ni}-\mathrm{Fe}$ sulfarsenides, diarsenides and triarsenides from the San Juan de Plan deposit, central Pyrenees, Spain. Canad Mineral 2004, 42(4), 1221-1240

Fanlo I, Subías I, Gervilla F, Manuel J (2006) Textures and compositional variability in gersdorffite from the Crescencia Ni-(Co-U) showing, Central Pyrenees, 
Spain: primary deposition or re-equilibration? Canad Mineral 44(6): 1513-1528

FÉRAUD J, DESChAMPS Y (2009) French scientific cooperation 2007-2008 on the Trepça lead-zinc-silver mine and the gold potential of Novo Brdo/Artana tailings (Kosovo). Final Report, BRGM/RP-57204-FR, pp 1-102

Ferenc S, Uher P, Spisiak J, Simonova V (2016) Chromium- and nickel-rich micas and associated minerals in listvenite from the Muránska Zdychava, Slovakia: products of hydrothermal metasomatic transformation of ultrabasic rock. J Geosci 61(3): 239-254

Frenzel M, Hirsch T, GutzMer J (2016) Gallium, germanium, indium, and other trace and minor elements in sphalerite as a function of deposit type-A meta-analysis. Ore Geol Rev 76: 52-78

Gervilla F, Fanlo I, Colás V, Subías I (2012) Mineral compositions and phase relations of $\mathrm{Ni}-\mathrm{Co}-\mathrm{Fe}$ arsenide ores from the Aghbar mine, Bou Azzer, Morocco. Canad Mineral 50(2): 447-470

Grapes RH, Challis GA (1999) Gersdorffite with pentlandite, violarite, pyrrhotite, and pyrite, northwest Nelson, New Zealand. New Zealand J Geol Geophys 42(2): 189-204

HARMs U (2010) Mineral chemistry of gersdorffite - A powerful tool in the differentiation of hydrothermal systems. Chem Erde 70(2): 175-184

Hem SR, Makovicky E (2004a) The system Fe-Co-NiAs-S. I. Phase relations in the $(\mathrm{Fe}, \mathrm{Co}, \mathrm{Ni}) \mathrm{As}_{0.5} \mathrm{~S}_{1.5}$ section at $650^{\circ}$ and $500^{\circ} \mathrm{C}$. Canad Mineral 42(1): 43-62

Hem SR, Makovicky E (2004b) The system Fe-Co-NiAs-S. II. Phase relations in the (Fe,Co,Ni)As ${ }_{15} \mathrm{~S}_{0.5}$ section at $650^{\circ}$ and $500^{\circ} \mathrm{C}$. Canad Mineral 42(1): 63-86

Hyseni S, Durmishaj B, Fetahaj B, Large D (2010a) Trepça ore belt and lead and zinc distribution in Badovc mineral deposit, Kosovo (SE Europe). J Eng Appl Sci 5(8): $1-9$

Hyseni S, Durmishaj B, Fetahaj B, Shala F, Berisha A, LARGE D (2010b) Trepça ore belt and stan terg mine - geological overview and interpretation, Kosovo (SE Europe). Geologija 53(1): 87-92

JANKOVIĆ S, ZARIĆ P (1980) Metallogenetic features of the antimony mineralization in the SE Kopaonik-Yugoslavia (Rajićeva Gora ore field). Trans Fac Min Geol 22: 43-56

Kiefer S, Majzlan J, Chovan M, Števko M (2017) Mineral compositions and phase relations of the complex sulfarsenides and arsenides from Dobšiná (Western Carpathians, Slovakia). Ore Geol Rev 89: 894-908

KIssin SA (1992) Five-element (Ni-Co-As-Ag-Bi) veins. Geoscience Canada 19(3): 113-124

KLemm DD (1965) Synthesen und Analysen in den Dreiecksdiagrammen FeAsS-CoAsS-NiAsS und $\mathrm{FeS}_{2}-$ $\mathrm{CoS}_{2}-\mathrm{NiS}_{2}$. Neu Jb Mineral, Abh 103: 205-255

Kolodziejczyk J, Pršek J, Melfos V, Voudouris PC, Maliqi F, KozUb-BudzyŃ G (2015) Bismuth minerals from the Stan Terg deposit (Trepça, Kosovo). Neu Jb Mineral, Abh 192(3): 317-333

KolodziejczyK J, PrŠEK J, Asllani B, Maliqi F (2016a) The paragenesis of silver minerals in the $\mathrm{Pb}-\mathrm{Zn}$ Stan Terg deposit, Kosovo: an example of precious metal epithermal mineralization. Geol, Geophys Environ 42(1): 19-29

Kolodziejczyk J, Pršek J, Voudouris P, Melfos V, AsLlani B (2016b) Sn-bearing minerals and associated sphalerite from lead-zinc deposits, Kosovo: An electron microprobe and LA-ICP-MS study. Minerals 6(2): 42

Kolodziejczyk J, PršEk J, Voudouris PC, Melfos V (2017) Bi-sulphotellurides associated with $\mathrm{Pb}-\mathrm{Bi}-$ $(\mathrm{Sb} \pm \mathrm{Ag}, \mathrm{Cu}, \mathrm{Fe})$ sulphosalts: an example from the Stan Terg deposit in Kosovo. Geol Carpath 68(4): 366-381 5

KretsChMAR U, ScOTT SD (1976) Phase relations involving arsenopyrite in the system $\mathrm{Fe}-\mathrm{As}-\mathrm{S}$ and their application. Canad Mineral 14: 364-386

Markl G, Burisch M, Neumann U (2016). Natural fracking and the genesis of five-element veins. Miner Depos 51(6): 703-712

Mederski S, Pršek J, Asllani B, Kozub-Budzyń G (2018) Bi-sulphosalts from the Mazhiq, Stan Terg area, Kosovo. $5^{\text {th }}$ Central-European Mineralogical Conference and $7^{\text {th }}$ Mineral Sciences in the Carpathians Conference, Banska Štiavnica, June 26-30, book of abstracts: 74

Mederski S, PrŠEK J, HincYNGIER K (2019) Pb-Zn-Sb$\mathrm{Ni}-\mathrm{Au}$ mineralization from the Kizhnica area, central Kosovo: new data on the listwaenite type mineralization. Proceedings of the Life with Ore Deposits on Earth: $15^{\text {th }}$ Biennial SGA Meeting, Glasgow, Scotland, August 27-30 2019; University of Glasgow Publicity Services: Glasgow, Scotland. 2: 834-837

Mikuš T, Chovan M, Ponomarenko O, Bondarenko S, GRINCHENKO O (2013) Hydrothermal nickel mineralization from the black shales in Čierna Lehota (Western Carpathians, Slovakia). Mineral J (Ukraine) 35(3): 27-32

Moroni M, Rossetti P, Naitza S, Magnani L, Ruggieri G, Aquino A, Oggiano G (2019) Factors Controlling Hydrothermal Nickel and Cobalt Mineralization - Some Suggestions from Historical Ore Deposits in Italy. Minerals 9(7): 429

QIU T, ZHU Y (2015) Geology and geochemistry of listwaenite-related gold mineralization in the Sayi gold deposit, Xinjiang, NW China. Ore Geol Rev 70: 61-79

Radosavljević S, Stojanović J, Kašić V (2011) Mineralogical and chemical study of gold in polymetallic ore of the Lece mine - Medvedja. Proceedings of the International October Conference on Mining and Metallurgy 43, Kladovo, Serbia: 437-440

Radosavljević SA, Stojanović JN, Vuković NS, RadosavljeVić-Mihajlović AS, Kašić VD (2015) Low-temperature $\mathrm{Ni}-\mathrm{As}-\mathrm{Sb}-\mathrm{S}$ mineralization of the $\mathrm{Pb}$ (Ag)-Zn deposits within the Rogozna ore field, SerboMacedonian Metallogenic Province: Ore mineralogy, 
crystal chemistry and paragenetic relationships. Ore Geol Rev 65: 213-227

Radosavljević SA, Stojanović JN, RadosavljevićMinaJlović AS, VuKović NS (2016) (Pb-Sb)-bearing sphalerite from the Čumavići polymetallic ore deposit, Podrinje Metallogenic District, East Bosnia and Herzegovina. Ore Geol Rev 72: 253-268

ReZaZadeh S, Hosseinzadeh MR, Raith JG, Moayyed M (2020). Mineral chemistry and phase relations of $\mathrm{Co}-\mathrm{Ni}$ arsenides and sulfarsenides from the Baycheh-Bagh deposit, Zanjan province, Iran. Ore Geol Rev 127: 103836

Scharrer M, KreissL S, MarkL G (2019) The mineralogical variability of hydrothermal native element-arsenide (five-element) associations and the role of physicochemical and kinetic factors concerning sulfur and arsenic. Ore Geol Rev 113: 1-28

Serafimoviki T, Stefanova V, Volkov AV (2010) Dwarf copper-gold porphyry deposits of the Buchim-Damjan-Borov Dol ore district, Republic of Macedonia (FYROM). Geol Ore Deposits 52(3): 179-195

Sharp ZD, Essene EJ, Kelly WC (1985) A re-examination of the arsenopyrite geobarometry: Pressure considerations and applications to natural assemblages. Canad Mineral 23: 517-534

StaJević B, Zarić P (1984) General characteristics of the ore paragenetic associations at Golija. In Proceeding of the II Symposium of the Yugoslav Association of Mineralogy, 251-260

Števko M, SejKora J (2020) Sb-enriched association of Ni arsenides and sulfarsenides from the Zemberg-Terézia vein system near Dobšiná (Western Carpathians, Slovak Republic). Bull Mineral Petrolog 28: 105-115

Stojanović JN, Radosavljević SA, Tošović RD, PačEvski AM, Radosavljević-Minajlović AS, Kašić VD, Vuković NS (2018) A review of the $\mathrm{Pb}-\mathrm{Zn}-\mathrm{Cu}-\mathrm{Ag}-$ $\mathrm{Bi}-\mathrm{W}$ polymetallic ore from the Rudnik ore field, Central Serbia. Geol An Balkan Poluostr 79(1): 47-69

Strmić Palinkaš S, Palinkaš LA, Renac C, Spangenberg JE, Lüders V, Molnar F, MaLiQI G (2013) Metallogenic model of the Trepča $\mathrm{Pb}-\mathrm{Zn}-\mathrm{Ag}$ skarn deposit, Kosovo: evidence from fluid inclusions, rare earth elements, and stable isotope data. Econ Geol 108(1): 135-162
Strmić Palinkaš S, Palinkaš L, Mandić M, Roller-LutZ Z, Pécskay Z, MaliQi G, Bermanec V (2016) Origin and $\mathrm{K}-\mathrm{Ar}$ age of the phreatomagmatic breccia at the Trepča $\mathrm{Pb}-\mathrm{Zn}-\mathrm{Ag}$ skarn deposit, Kosovo: Implications for ore-forming processes. Geol Croatica 69(1): 121-142

Tombros S, St. Seymour K, Williams-Jones AE, Spry PG (2007) The genesis of epithermal Au-Ag-Te mineralization, Panormos Bay, Tinos Island, Cyclades, Greece. Econ Geol 102(7): 1269-1294

VAVELIDIS M, MeLFos V (2004). Bi-Ag-bearing tetrahedritetennantite in the Kapsalina copper mineralisation, Thasos Island, Northern Greece. N Jb Minerl, Abh 180(2): $149-170$

Voudouris P, Melfos V, Spry PG, Bonsall tA, Tarkian M, Solomos C (2008) Carbonate-replacement Pb-Zn$\mathrm{Ag} \pm \mathrm{Au}$ mineralization in the Kamariza area, Lavrion, Greece: Mineralogy and thermochemical conditions of formation. Mineral Petrol 94(1-2): 85

Voudouris P, Mavrogonatos C, Rieck B, Kolitsch U, Spry PG, Scheffer C, Zaimis S (2018) The gersdorffite-bismuthinite-native gold association and the skarnporphyry mineralization in the Kamariza mining district, Lavrion, Greece. Minerals 8(11): 531

WatKinson DH, Heslop JB, Ewert WD (1975) Nickel sulphide-arsenide assemblages associated with uranium mineralization, Zimmer Lake area, northern Saskatchewan. Canad Mineral 13(2): 198-204

Węgrzynowicz J, Pršek J, Mederski S, Asllani B, KwIECIEŃ K, KANIGOWSKI J (2019) $\mathrm{Pb}-\mathrm{Bi}(-\mathrm{Cu})$ and $\mathrm{Pb}-\mathrm{Sb}$ sulfosalts from Stan Terg area, Kosovo. Proceedings of the Life with Ore Deposits on Earth: $15^{\text {th }}$ Biennial SGA Meeting, Glasgow, Scotland, August 27-30 2019; University of Glasgow Publicity Services: Glasgow, Scotland 1,380-383

Wojslaw M, PršEK J, Medersski S, Asllani B, KanigowsKI J (2019) Chemical characteristic of gersdorffite solid solutions in Stan Terg area, Kosovo. Proceedings of the Life with Ore Deposits on Earth: $15^{\text {th }}$ Biennial SGA Meeting, Glasgow, Scotland, August 27-30 2019; University of Glasgow Publicity Services: Glasgow, Scotland 4, $1875-1878$

Yund RA (1962) The system Ni-As-S; phase relations and mineralogical significance. Amer J Sci 260: 761-782 